\title{
Cranial anatomy of the aetosaur Paratypothorax andressorum LoNG \& BALLEW, 1985, from the Upper Triassic of Germany and its bearing on aetosaur phylogeny
}

\author{
Rainer R. Schoch and Julia B. Desojo
}

With 8 figures

\begin{abstract}
The large aetosaur Paratypothorax andressorum has so far been known only by its osteoderms. Here we describe for the first time the skull of a complete, articulated specimen of this taxon that was found in the type horizon at Murrhardt, southwestern Germany. Paratypothorax andressorum has the following cranial autapomorphies: (1) upper jaw margin with deep notch between premaxilla and maxilla, (2) maxilla-lacrimal suture with finger-like projection, (3) upper temporal fenestra triangular, and (4) first paramedian cervical osteoderms narrow and oval, much smaller than second row. Apart from these features, the skull of $P$. andressorum closely resembles that of the small aetosaur Aetosaurus ferratus known from the same horizons, despite major differences in the morphology of osteoderms. Both taxa share (1) the pointed, beak-shaped premaxilla which expands only gently anterior to the nasal, (2) maxilla and lacrimal excluding jugal from margin of antorbital fenestra, (3) exclusion of squamosal from margin of infratemporal fenestra, and (4) posterior part of jugal not downturned. Phylogenetic analysis reveals poorly resolved relationships within Aetosauria, but exclusion of a problematic taxon Coahomasuchus results in a much better resolution, with Paratypothorax to nest with Rioarribasuchus, Tecovasuchus, Typothorax, and Redondasuchus within a monophyletic Typothoracinae. Interestingly, Aetosaurus and Stenomyti form successive sister taxa of this clade rather than fall within an aetosaurine grade of basal aetosaurs, as suggested by previous authors.The resemblance of Paratypothorax and Aetosaurus in many cranial features, their close relationship as suggested by the present analysis, and the immature state of all available Aetosaurus specimens suggest two new alternative hypotheses: (1) Aetosaurus is the juvenile of a close relative of Paratypothorax or (2) it is itself the juvenile of Paratypothorax.
\end{abstract}

Key words: Aetosaurus, Archosauria, Löwenstein Formation, Norian, Pseudosuchia.

\section{Introduction}

Aetosaurs form a distinctive clade of quadrupedal archosaurs, which was first recognized on the basis of a spectacular find from Germany. This encompassed 24 articulated skeletons of the name-bearing genus $\mathrm{Ae}$ tosaurus. They were recovered on a single block in a small quarry at the village of Kaltental, now a suburb of
Stuttgart (FrAAS 1877). These heavily armoured pseudosuchians were soon reported from other Upper Triassic deposits in Europe and North America, and among the first finds were large osteoderms from a locality very close to the original Aetosaurus site, at Heslach in Stuttgart. In fact, some of these isolated osteoderms were reported before the discovery of Aetosaurus itself and initially referred to another archosauriform: 


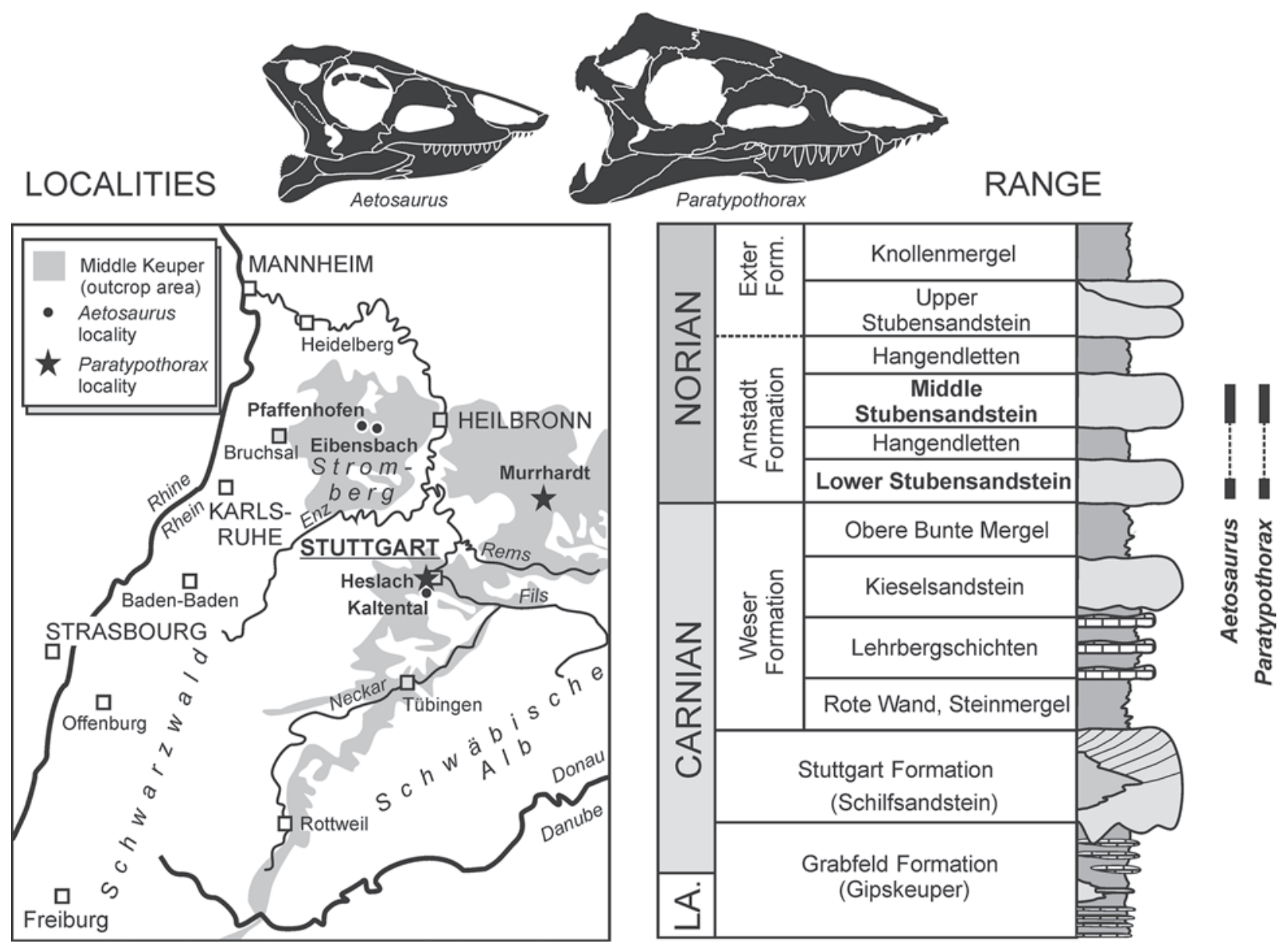

Fig. 1. Map of southwestern Germany showing exposures of Keuper strata (light grey) and with locations of aetosaur-bearing sites.

the phytosaur Belodon (Meyer 1861, 1865; HungerBÜHLER 2002). More than a century later, some of these osteoderms, of elongated rectangular shape and with a marked boss in the centre, were recognized as belonging to a large aetosaur, for which the new generic name Paratypothorax was erected by LONG \& BALLEW (1985).

Aetosaurs were long defined on the basis of their osteoderms, which differ in length, proportion, and ornament (Long \& BALLew 1985; Desojo et al. 2013). Because the skull is not well known in many taxa, it was not a major source of characters in previous phylogenetic analyses. The general notion was that cranial morphology differed little, with Aetosaurus forming a basal taxon with Aetosauroides from South America (CASAmiquela 1960; Walker 1961). Its beak-shaped snout, which led FrAAS (1877) to coin the name Aeto- saurus ('eagle lizard'), is generally considered to form the plesiomorphic condition of aetosaurs, with most of the taxa sharing a laterally expanded, shovel-like tip. Such morphology was also hypothesized for Paratypothorax, which on the basis of its armour osteoderms was ranked with the North American shovel-snouted Typothorax and Desmatosuchus (HeCKert \& LuCAS 1999, 2000; HeCKerT et al. 2010).

In 1945, a nearly $2 \mathrm{~m}$ long skeleton was found in a small sandstone quarry near Murrhardt, southern Germany. Because it was believed to be a phytosaur by the osteoderm morphology, the relatively small skull was not readily identified in the unprepared block, and the postcranium considered not important enough for preparation. In 2002, preparation revealed that the Murrhardt find was actually a complete skeleton of Para- 
typothorax, fortunately with one of the best-preserved skulls in aetosaurs. Surprisingly, this skull resembles that of Aetosaurus, notably in the snout, which is also beak-shaped. At closer inspection of the skull, similarities between Paratypothorax and Aetosaurus mounted, prompting a phylogenetic reconsideration of the group as a whole.

The objectives of the present contribution are twofold: (1) describe in detail the cranial anatomy of Paratypothorax, and (2) assess the phylogenetic position of the taxon in the framework of Aetosauria as a whole, with a particular focus on the identification of additional cranial characters.

\section{Material and methods}

SMNS 19003 is a complete adult skeleton referred to Paratypothorax andressorum based on the following combination of characters: armour with anterior bars, dorsal paramedian osteoderms greatly expanded (width 3.5 times its length), radiate ornamentation, small to very large eminences on the paramedian osteoderms situated medially, and horns on the lateral osteoderms of the dorsal region (LONG \& BALLEW 1985). The specimen was discovered in 1945 by workers in the Schlipf quarry at Köchersberg, Murrhardt, Baden-Württemberg, Germany (Fig. 1). The skeleton was exposed by a controlled detonation in the basal sandstone layers of the $16 \mathrm{~m}$ deep quarry cliff. It was mentioned that it came out of a horizon $\sim 1 \mathrm{~m}$ above the base level of the quarry, and that it was found ventral side down. BERCKHEMER (1949) reported the damage caused by the detonation as severe and considered the specimen to be incomplete, lacking the skull. Therefore, it was left unprepared for decades.

However, preparation revealed a beautifully articulated skeleton, including the skull, with all osteoderms in life-like positions, the body as a whole leaned towards the right side and affected by compaction (Fig. 2D, F, G). The right paramedian osteoderms and the right side of the skull are slightly compressed and unnaturally kinked. Apart from distortion, the preservation is excellent. The bones are purple to brown in coloration, covered by a hematite crust. In the trunk region, the outer $2 \mathrm{~cm}$ of sediment are impregnated by hematite, which is concentrated along irregular lines in places paralleling the armour osteoderms (Fig. 2). Further preparation is hoped to reveal more details of the limbs and girdles where osteoderms permit their exposure, and to eventually reveal the ventral osteoderms.

\section{Systematic palaeontology}

\author{
Archosauria Cope, 1869 sensu GAUthiER \& PAdian, \\ 1985 \\ Pseudosuchia Zittel, 1890 sensu Gauthier \& PAdian, \\ 1985 \\ Aetosauria MARSH, 1884 \\ Paratypothorax Long \& BALLEw, 1985
}

Type species: Paratypothorax andressorum LonG \& BALLEW, 1985.

Diagnosis: As for type species.

Paratypothorax andressorum LoNG \& BALLEw, 1985 Figs. 2-7

Holotype: SMNS 5721, postcranial remains belonging to one large individual. Osteoderms: 15 right paramedian, 22 left paramedian, 11 lateral, an ischium, and a tibia.

Type horizon and locality: Middle (second) Stubensandstein, Löwenstein Formation (Late Triassic: Middle Norian). There exists some confusion about the stratigraphic position of the type locality (HECKERT \& LuCAS 2000), but stratigraphers focusing on regional Triassic localities agree that the Heslach quarry falls within the Middle Stubensandstein (BRENNER 1978; SeEgis 1986, 2005). Heslacher Wand, Stuttgart suburban area, Baden-Württemberg, Germany.

Stratigraphic range: Lower Stubensandstein (Murrhardt) through Middle Stubensandstein (Heslach, Stuttgart-Gablenberg, Kayh, Gerlingen), according to Etzold \& Schweizer (2005) both falling within the $\mathrm{k} 5$ phase of the Keuper sequence, which ranges within the Middle Norian (Alaunian).

Revised diagnosis: Medium-sized aetosaur (around two meters in total length) distinct from other aetosaurs by the following combination of characters (autapomorphies indicated by an asterisk): upper jaw margin with deep notch between premaxilla and maxilla*; supratemporal fenestra triangular with rounded edges*; nuchal osteoderms narrow and oval, much smaller than the first paramedian row*; maxilla-lacrimal suture with a finger-like ventral projection of the maxilla (like in Stenomyti, polymorphic in Aetosaurus); antorbital fossa formed by the maxilla and lacrimal only, excluding jugal from the margin of the antorbital fenestra (as in Aetosaurus and Stenomyti); exclusion of squamosal from the infratemporal margin (as in Aetosaurus); posterior part of jugal not downturned (as in Aetosaurus and Stenomyti); premaxilla forming a beak, without shovel-shaped expansion (as in Aetosaurus and Stenomyti); premaxillary tooth row begins anterior to spike-like projection on that bone (as in Aetosaurus and Neoaetosauroides), ventral process of postorbital longer and stouter than in most aetosaurs (as in Aetosaurus); postfrontal-parietal suture extensive (as in Aetosaurus, Stenomyti, and Neoaetosauroides); posterior dentary region divided into two projections that form the 


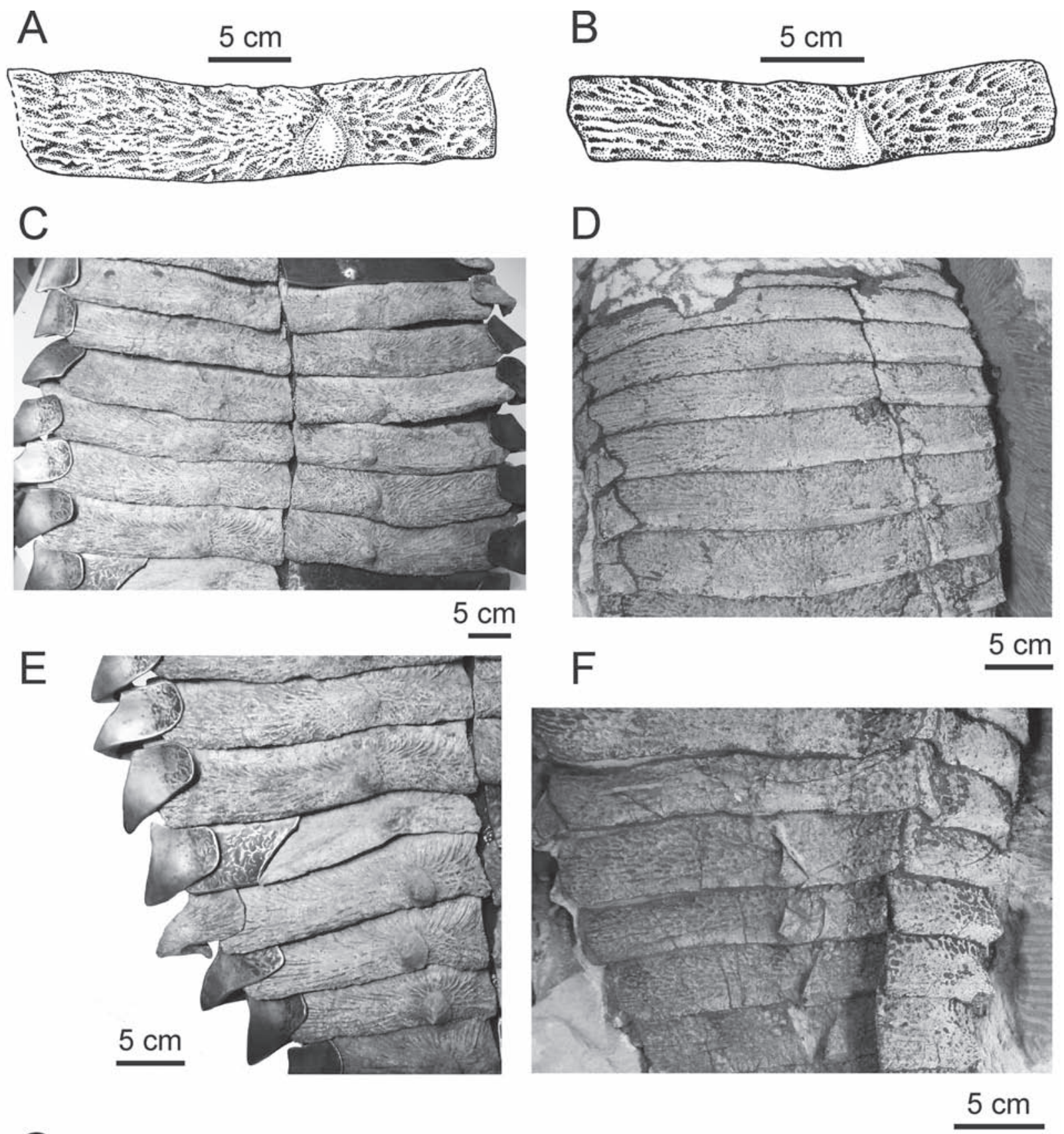

G

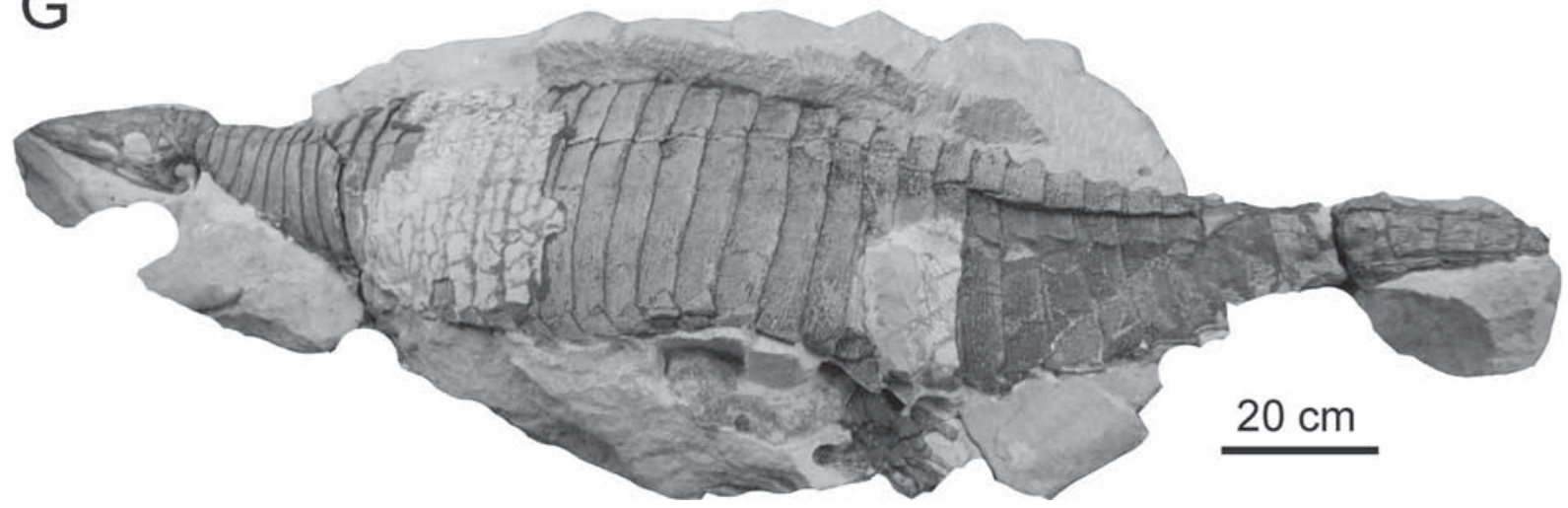

Fig. 2. 
anterior margin of the external mandibula fenestra, the dorsal projection being longer than the ventral (as in Aetosaurus and Stagonolepis robertsoni); retroarticular process with articular dorsal projection (as in Aetosaurus and Stagonolepis), nuchal osteoderms without lateral osteoderms, and paramedian osteoderms with anterior bar, radial pattern, and high (more than 3.5:1) width: length ratio (as in Typothorax and Rioarribasuchus).

Comments on osteoderm characters: The type specimen is diagnostic by the consistent possession of radial grooves and ridges in all osteoderms and the position and shape of the dorsal eminence, both shared by the referred specimen (SMNS 19003; Fig. 2A, B). The dorsal eminence reaches the posterior margin of the plate, but its height varies substantially with the position of the plate: first appearing in the anterior trunk, the eminence becomes increasingly higher in the posterior trunk and bear the characteristic spikes mentioned in former papers (e.g., HECKERT \& LUCAS 2000) only at the base of the tail. The same variation is present in SMNS 19003, only that the eminences are slightly lower than in the type, which we here interpret as ontogenetic rather than taxonomically significant. Differences in ornament are also likely to be caused by growth: the plates of the type specimen are disproportionately thicker than those of smaller specimens, including isolated smaller plates from the type locality, which are consistent with SMNS 19003.

In summary, the close resemblance of outline and ornament of the paramedian plates, as well as the structure of the dorsal eminence indicate that SMNS 19003 and the type specimen belong to the same taxon (Fig. 2). This is confirmed by the phylogenetic analysis, which finds SMNS 19003 and the type specimen, here coded as separate OTUs, to nest as "sister taxa".

Referred material: SMNS 12958, three articulated and fused paramedian osteoderms, Lower Stubensandstein of Stuttgart-Gablenberg (LuCAS 2000). SMNS 19003 (first described herein), a complete articulated specimen measuring $212 \mathrm{~cm}$ from the Lower Stubensandstein of Murrhardt. SMNS 51437, an osteoderm from the Lower Stubensandstein of Busch quarry, Gerlingen; SMNS 59750 (cast of an unnumbered Tübingen original), a lateral osteoderm from Kayh quarry; Several specimens from the United States have been assigned to Paratypothorax based on isolated osteoderms (see Long \& BALlew 1985; Hunt \& LuCAS 1992; LonG \& Murry 1995; HecKert \& LuCAs 2000; LucAs et al. 2006), from Arizona, New Mexico, Texas, and the Fleming Fjord Formation (Greenland) to P. andressorum. However, Long \& MurRy (1995) argued that the North American material was distinct from the German specimens. For the same reason, we keep them separate until a complete analysis of the North
American material has been undertaken. Likewise, the isolated osteoderm records referred to Paratypothorax in North Africa (Jalil et al. 1995) and India (KutTy \& SENGUPTA 1989) is not discussed herein, because it is not the scope of this contribution and will be part of the postcranial study of the SMNS 19003 in the near future.

\section{Description}

\subsection{General remarks}

The fully articulated skull is $18.5 \mathrm{~cm}$ long, comprising only $8.7 \%$ the length of the body $(212 \mathrm{~cm})$. The skull is distorted, flattened to the right side and exposed with the left lateral side facing dorsally. The palate is only partially visible, with the anterior portion of the palatine and the complete vomer obscured by the articulated mandible. In turn, the mandible is attached to the inner side of the upper jaws, thus partially obscured by the premaxilla and maxilla. An isolated bone that is attached to the posterior end of the mandible is identified as hyoid element. The cervical paramedian osteoderms are fully articulated, with the first (nuchal), relatively narrow pair overlapping the posterior margin of the parietal. Despite the distortion, the bones are in excellent condition and there are very few minor cracks. The ornament, which is pronounced in many osteoderms and on the skull table, is well preserved (Figs. 2-4).

The general outline of the skull is triangular in dorsal and lateral views, having a pointed snout and being tallest at the posterior margin of the parietal (Figs. 3-7). The preorbital region comprises $64 \%$ the length of the skull. Like in Aetosaurus and Stagonolepis, the medial portions of the skull roof bear continuous grooves that converge anteriorly in a point on the nasal, level with the posterior narial margin and which meet in a straight transverse groove on the posterior half of the parietal. The margins of these grooves are raised and bear numerous irregular bosses and tubercles. These bosses are consistent with those in ornamented areas on the centre of the frontals and parietals, but markedly more pronounced than these. When comparing cranial features of Paratypothorax to those of other taxa, we make use of the following literature: DEsojo \& BÁEz (2007) and

Fig. 2. Postcranial morphology of Paratypothorax andressorum. A, B - Paramedian plates from mid-trunk region. C-F Paramedian and lateral osteoderms in articulation. G - Present state of the complete skeleton first described herein. A, C, E: SMNS 5721 (type specimen from Heslach). B, D, F, G: SMNS 19003 (referred specimen from Murrhardt). 

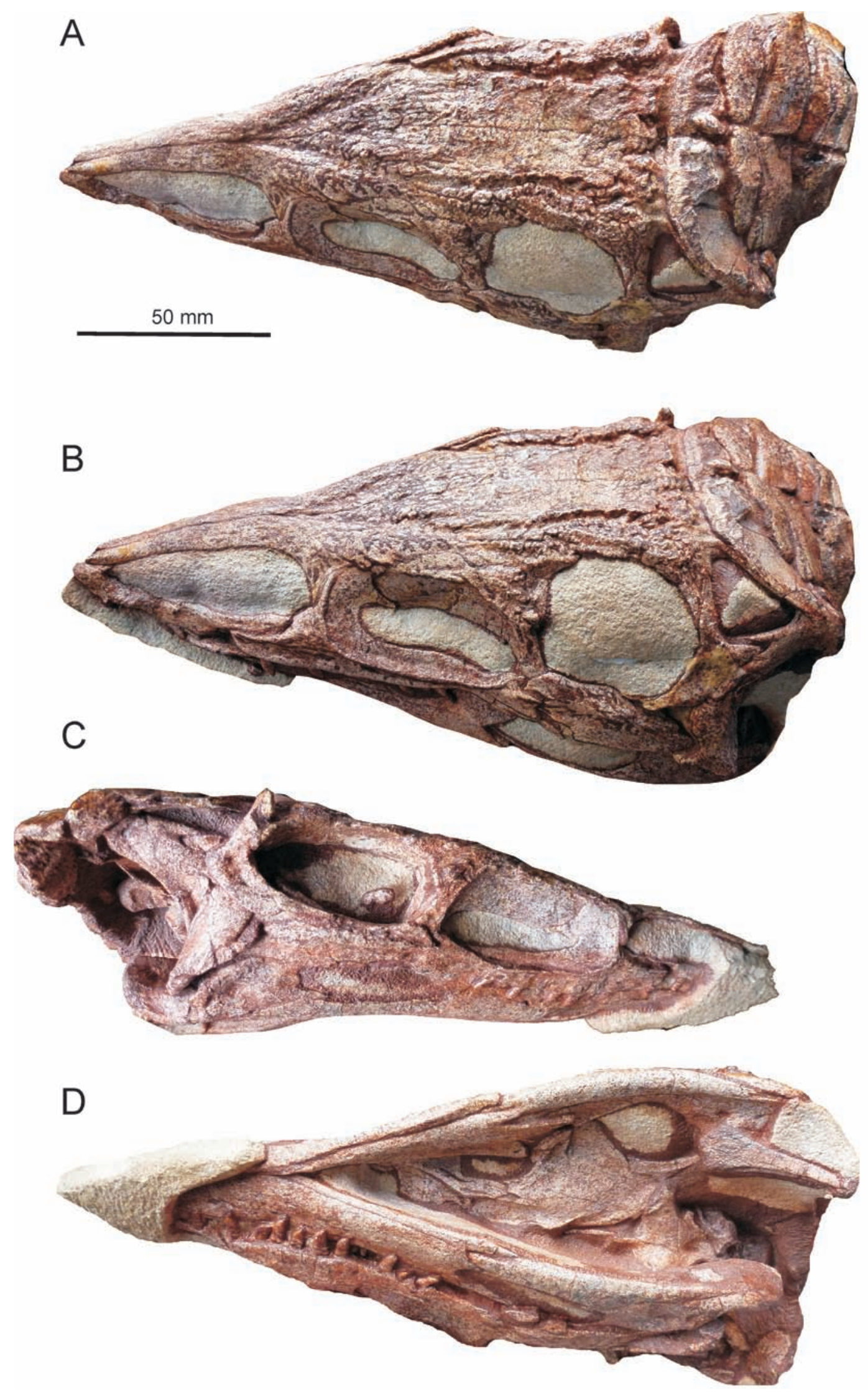

Fig. 3. 

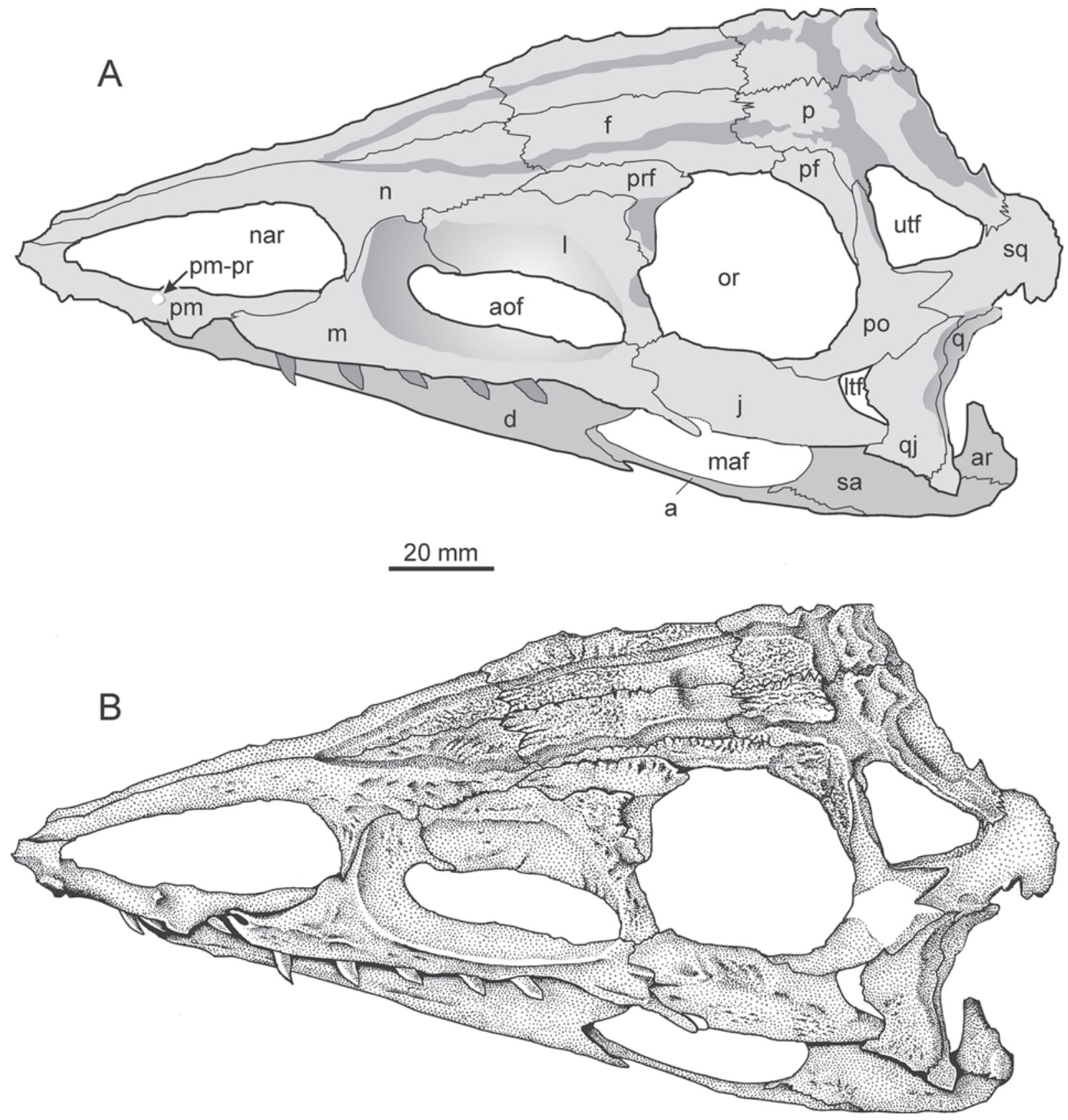

Fig. 4. Skull of Paratypothorax andressorum, left lateral view (SMNS 19003). Abbreviations: a, angular; aof, antorbital fenestra; ar, articular; d, dentary; f, frontal; j, jugal; 1, lacrimal; ltf, lower temporal fenestra; m, maxilla; maf, mandibular fenestra; n, nasal; nar, naris; or, orbit; p, parietal; pf, postfrontal; pm, premaxilla; pm-pr, thorn-like premaxilla projection; po, postorbital; prf, prefrontal; q, quadrate; qj, quadratojugal; sq, squamosal; utf, upper temporal fenestra.

Fig. 3. Skull of Paratypothorax andressorum (SMNS 19003). A - Dorsal view; B - left lateral view; C - right lateral view; D - ventral view. 

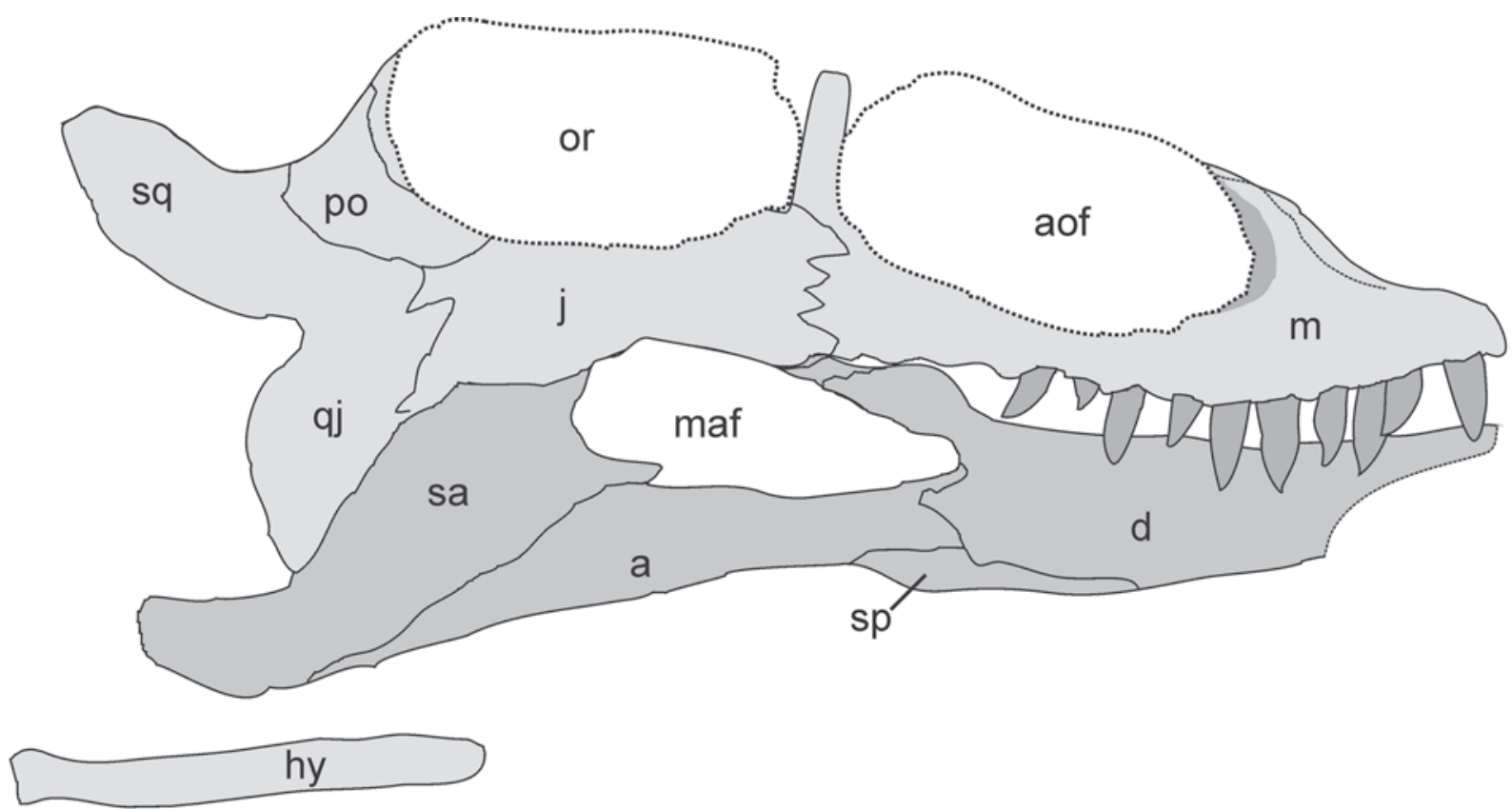

$20 \mathrm{~mm}$

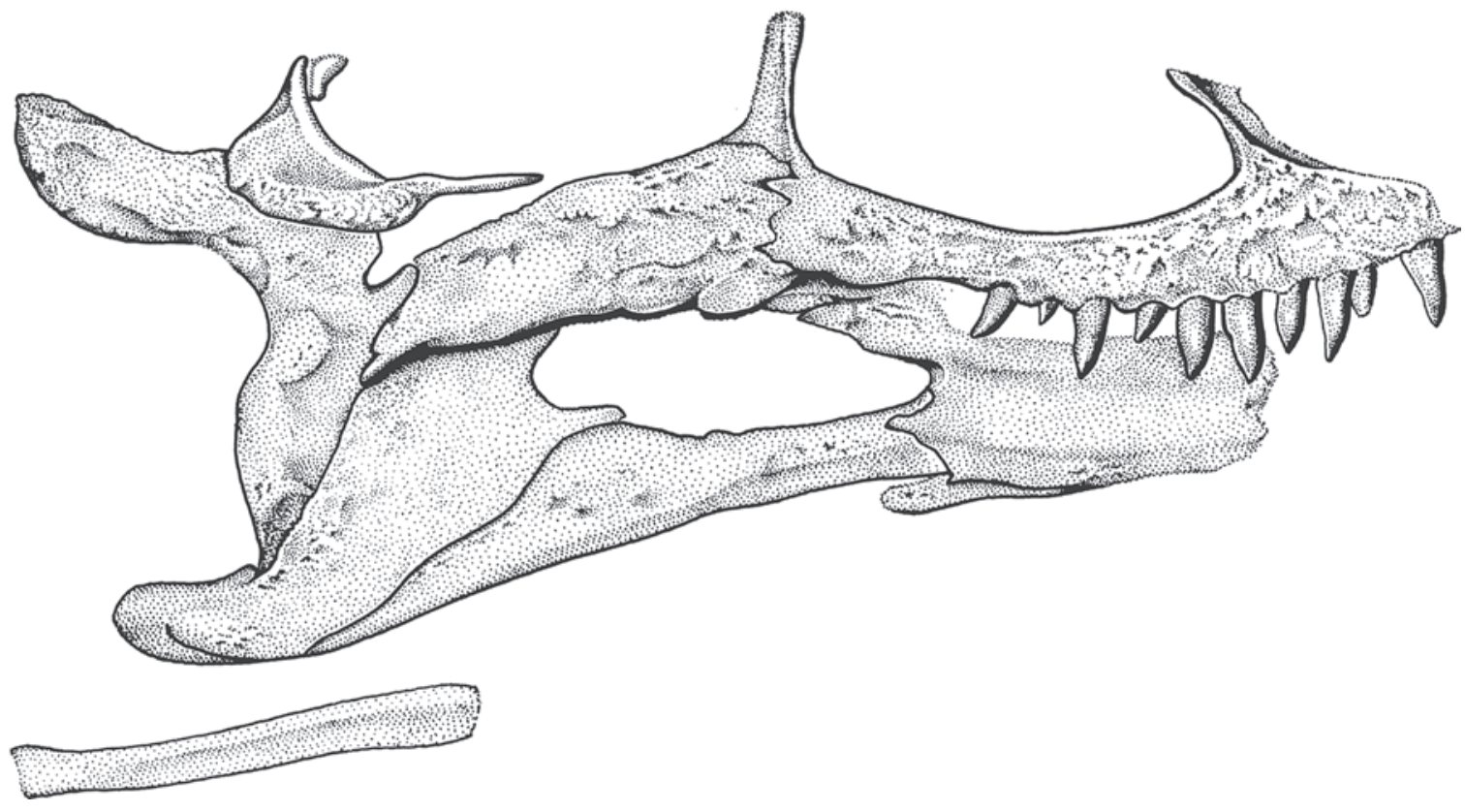

Fig. 5. Skull of Paratypothorax andressorum, right lateral view (SMNS 19003). Abbreviations: sa, surangular; sp, splenial; for others see Fig. 4.

Desojo \& VizCAíno (2009) on Neoaetosauroides engaeus, Desojo \& HeCKert (2004) on Coahomasuchus kahleorum, Heckert et al. (2010) on Typothorax cocci- narum, MARTZ \& SMALL (2006) on Tecovasuchus chatterjeei, PARKer et al. (2005) on Revueltosaurus callenderi, PARRISH (1994) and SAWIN (1947) on Longosuchus 
meadei, ScHосн (2007) on Aetosaurus ferratus, SMALL (2002) and PARKer (2008) on Desmatosuchus smalli and D. spurensis, respectively; SMALL \& MARTZ (2013) on Stenomyti huangae, Desojo \& Ezcurra (2011) on Aetosauroides scagliai, and WALKER (1961), GOWER \& WALKer (2002), and Sulej (2010) on Stagonolepis robertsoni and $S$. olenkae, respectively.

\subsection{General remarks}

Consistent with other archosaurs, the skull has five paired openings: the oval and anteriorly pointed external naris, the markedly shorter reniform antorbital fenestra, the round orbit, the triangular supratemporal fenestra, and a tiny infratemporal fenestra (Figs. 3-5).

\subsection{Premaxilla}

The left premaxilla is almost completely exposed, whereas the right one is broken off at the tip (Figs. 3-4). It is a long, slender bone comprising the anterior and ventral margin of the external naris, with the maxilla articulating posteriorly, forming a marked notch at the level where the suture meets the upper jaw margin. The posterior portion of the premaxilla overlaps the anterior process of the maxilla, by that forming almost the entire ventral margin of the naris and exposing only a narrow strip of the maxilla at the narial margin. The anterior portion of the premaxilla is overlapped by the nasal, as in the case of most of the aetosaur. This region is broken and therefore not fully preserved. The premaxilla tapers continuously towards the tip, forming a gentle lateral projection level with the anterior fourth of the naris. The tip itself appears to have been unexpanded as in Aetosaurus and Stenomyti, and is rather different from the shovel shape premaxilla in most other aetosaurs. The premaxilla houses at least four thecodont teeth that are slightly smaller than those of the maxilla, but of similar shape. They are consistent in size and shape, the last one located close to the premaxilla-maxilla articulation, as in other aetosaurs (e.g., Neoaetosauroides, Aetosaurus, Stagonolepis, Stenomyti), in contrast with the edentulous premaxilla of Desmatosuchus. The posteriormost tooth is well behind the thorn-like projection on the lateral flank of the premaxilla (Fig. 4, pm-pr), a tooth position shared solely with Aetosaurus. The thorn-like projection is shared with most aetosaurs, and its poor development in Stenomyti and Aetosaurus suggests that the feature was subject to ontogenetic change.

\subsection{Maxilla}

The maxilla is anteroposteriorly elongated with a nearly straight ventral margin and a tall facial process borne by the anterior half of the element (Figs. $3-6)$. The anterior process is short (1/4 of the maxilla length) and slightly curved dorsally, contributing to the marked notch at the suture with the premaxilla. This process is overlapped by the posterodorsal process of the premaxilla, which fails to contact the nasal only by a short distance. The height of the facial process measures about half the length of the maxilla, as in most aetosaurs except Aetosauroides. Its anterior margin is concave, accommodating the ventral projection of the nasal, whereas the posterior margin bears a large finger-like posterior projection extending along the ventral margin of the lacrimal.

The posterior process of the maxilla is elongate and largely straight, with the exception of a marked notch along its ventral margin in its posterior portion. Its posterior end is three-pronged, including (1) a small dorsal projection wedged between the lacrimal and jugal, (2) a posterior projection interfingering with the jugal, and (3) a spike-like posteroventral process that extends along the ventral margin of the jugal. This condition is also present in Aetosaurus, but differs from all other aetosaurs.

The tip of the anterior process has a distinctive anterior recess, with two small branches that enclose a small oval depression. At the same level of this recess, close to the ventral margin there is a longitudinal depression that extends on the lateral surface of the left maxilla anteroposteriorly. The smooth antorbital fossa is extensive, as in the case of Stagonolepis, Aetosaurus, and Stenomyti, demarcated by a continuous crest running from the dorsal margin of the facial process to the posterior end of the element. The crest has a semicircular outline, anteriorly merging into an elevated, ornamented platform, resembling the condition in Aetosaurus, in contrast with Desmatosuchus where it is absent. The narrow part ventral to the crest bears a range of pits and short grooves.

\subsection{Nasal}

The nasal is by far the longest bone in the skull roof, comprising $42 \%$ the skull length. Its anterior two-thirds form the dorsal margin of the external naris (Figs. 3-4). The anterior tip of the nasal overlaps the premaxilla, which is exposed lateral to it. The nasal forms a muchelongated triangle, having a smooth anterior region and 

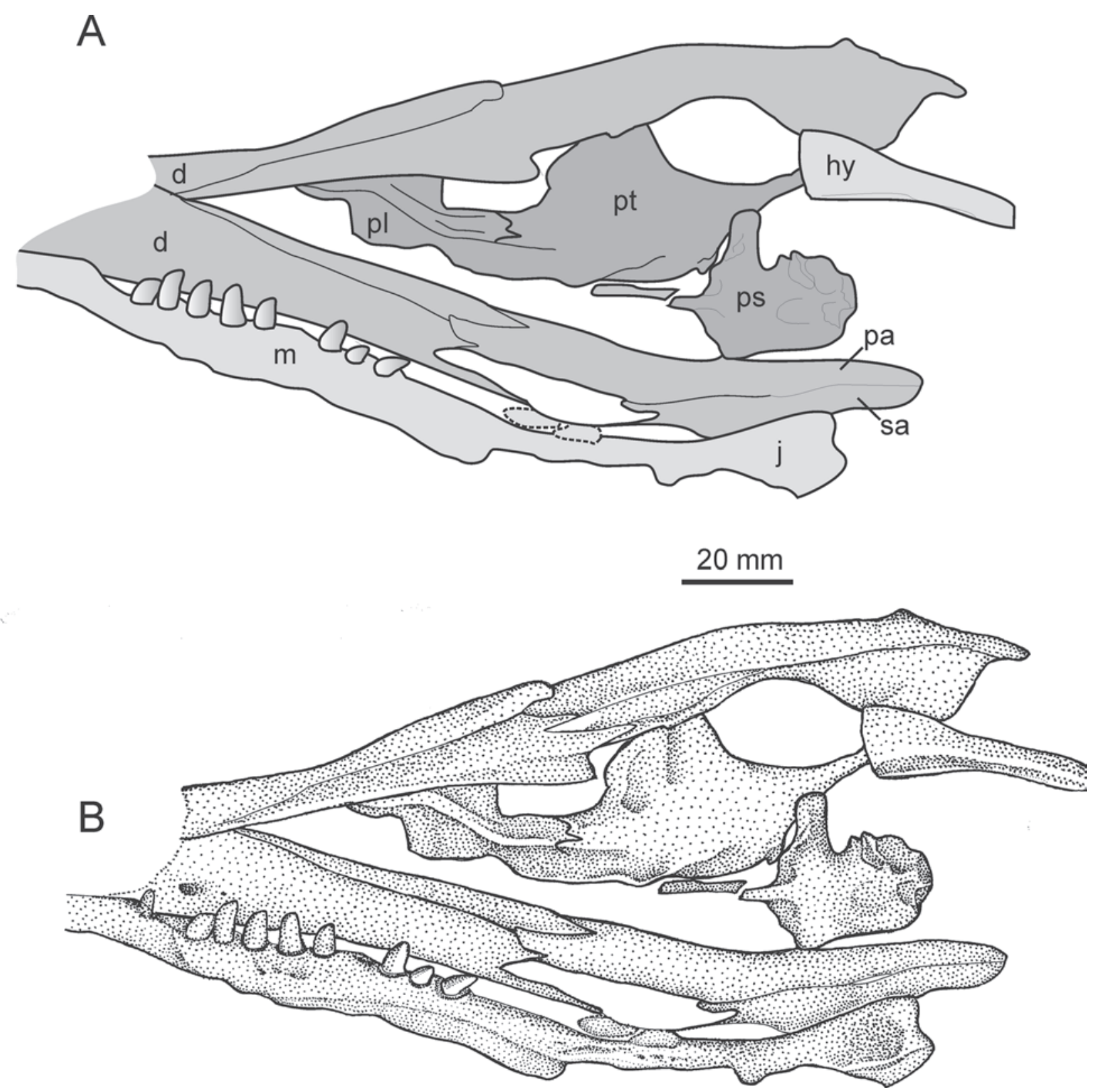

Fig. 6. Skull of Paratypothorax andressorum, ventral view (SMNS 19003). Abbreviations: hy, hyoid element; pa, prearticular; pl, palatine; ps, parasphenoid; pt, pterygoid; for others see Fig. 4.

a distinctly ornamented posterior portion, covered by pits and parallel grooves. In the posterior half, a spikelike ventrolateral process contacts the facial process of the maxilla, forming the posterior margin of the naris. This process is shared with Aetosaurus, Aetosauroides, Stenomyti, and Stagonolepis. The naso-frontal suture is transversely long and tight, extensively interdigitating. As in Aetosauroides, it is located at the mid-level of the antorbital fenestra, in contrast to the posterior- level in other aetosaurs, including Aetosaurus (SMNS 5770-S16) and Neoaetosauroides (PVL 4363). Laterally, there is a short contact between the nasal and prefrontal, which ends in a point.

\subsection{Frontal}

The frontal is rectangular in dorsal view, reaching only half the length of the nasal. It has a transverse suture 
with the nasal anteriorly and parietal posteriorly, contacting the prefrontal and postfrontal laterally (Figs. 3-4). The frontal forms the dorsal margin of the orbit, making about an equal contribution as the prefrontal and postfrontal. The sutures with these bones are not very clear on the dorsal surface, but are well defined on the ventral side, in the roof of the orbit. The dorsal surface of the frontal is slightly ornamented with pits close to the suture and lateral margins, and a deep elongated groove that is wider and deeper posteriorly.

\subsection{Parietal}

The parietal is slightly shorter than the frontal (Fig. 4A). It is quadrangular in dorsal view, suturing with the frontal anteriorly, the postfrontal and postorbital laterally, and the squamosal posterolaterally (Figs. 3-4). The parietal is separated into a flat skull-roofing anterior portion and an oblique, posteroventrally sloping occipital portion. The anterior portion is heavily ornamented, bearing numerous bosses except for the very profound groove on the lateral side and the immediate margin of the supratemporal fenestra. This region is much shorter than in other aetosaurs, notably Aetosaurus, where the parietal margin of the supratemporal fenestra is more oval. The posterior or occipital portion is separated from the anterior one by a deep transverse groove, which merges into the margin of the supratemporal fenestra, like in Desmatosuchus spurensis (pers. comm. W. PARKer 2015). The occipital portion has a semicircular anterior margin, medially bordering the groove, laterally forming the raised margin of the supratemporal fenestra. The posterior margin of the occipital portion has a rugose surface, which extends posteromedially to form a shelf. The medial margin of the shelf bears a parasagittal swelling, separated from the opposite side by a narrow sagittal groove, within which the midline suture is emplaced. In Aetosaurus (SMNS 5770 S2), the shelves are separated by a wide gap, whereas in Stenomyti they are confluent; both taxa lack the pronounced paramedial swellings of Paratypothorax. An intermediate condition, with a wide gap, but a pronounced paramedial swelling is present in Stagonolepis. The posterior margin of the parietals is obscured by the first pair of paramedian osteoderms. The occipital portion contacts the squamosal in a serrated suture, together forming the posteriormost tip of the skull roof. The parietal forms most of the posterodorsal margin of the supratemporal fenestra, as in the case of most of the aetosaurs, except Desmatosuchus.

\subsection{Lacrimal}

The lacrimal forms most of the dorsal and posterior margins of the antorbital fenestra (Figs. 3-4). The largest portion of the bone is smooth, contributing to the antorbital fossa. As in Aetosaurus, but much less pronounced, the smooth area bears a thin ridge running obliquely from the point where the maxilla projection ends to the dorsal margin of the fossa (Fig. 7). The dorsal margin of the fossa is very distinctive, forming a flange along its posterior end. The dorsal portion of the lacrimal is covered with bosses and pits, and a deep large pit at the orbit margin housed the lacrimal foramen. Both maxilla and jugal overlap the descending part of the lacrimal. The lacrimal extends far anteriorly, almost level with the anterior margin of the antorbital fenestra. This condition is shared with Aetosaurus, Stenomyti, and Aetosauroides. The ventral process of the lacrimal contacts the maxilla and jugal, a state that also occurs in Aetosaurus, Stenomyti, and Longosuchus.

\subsection{Prefrontal}

The prefrontal is a three-pronged element, with an elongate anterior process wedging deeply between the lacrimal, frontal and nasal, a substantial lateral process extending along the orbit margin, and a short posterior process, separated from the postfrontal by a posteroventral portion of the frontal (Figs. 3-4). Among aetosaurs, such an anterior extension of the prefrontal is also present in Aetosaurus (e.g., SMNS 5770 S-16), Desmatosuchus spurensis (PARKER 2008), Stagonolepis (Sules 2010), and absent only in Aetosauroides (DesoJO \& EzCURRA 2011) and Longosuchus (PARRISH 1994) (Fig. 7). The lateral margin is markedly concave similar to the condition in Aetosaurus. It is heavily ornamented except for the lateral process along the orbit margin. The dorsal region of the prefrontal contacts the frontal in a markedly raised, bulbous margin.

\subsection{Postfrontal}

The postfrontal is smaller than the prefrontal, forming part of the posterodorsal orbit margin (Figs. 3-4). It is overlapped by the ascending process of the postorbital. The suture with the frontal is short, that with the parietal much longer. The postfrontal is heavily ornamented, in contrast to the adjoining postorbital. Like in Aetosaurus, Stenomyti, Neoaetosauroides, and Longosuchus, the postfrontal has a substantial contact with the parietal (Fig. 7). 
A

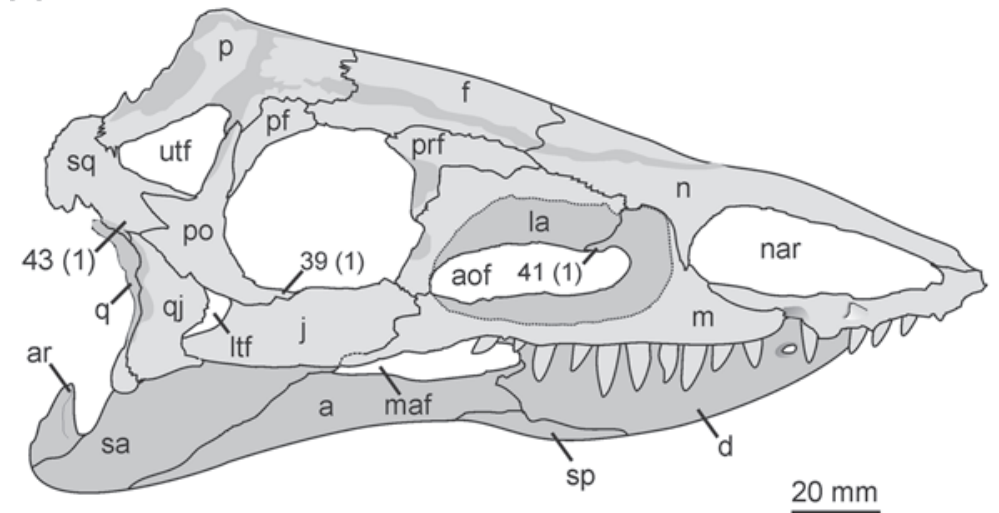

C

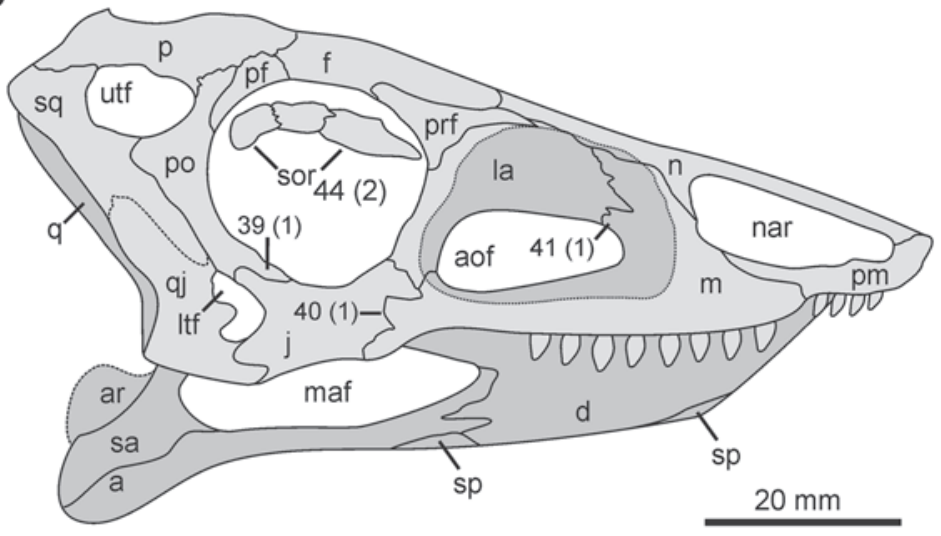

E

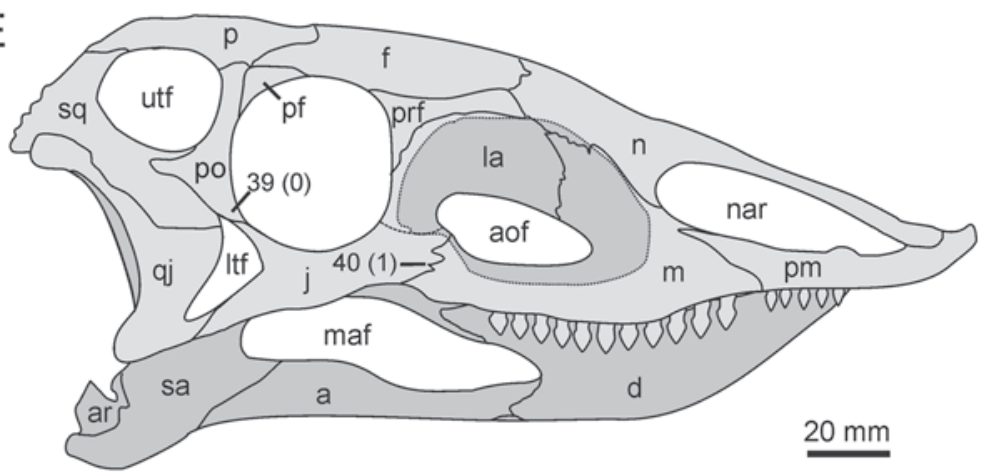

G

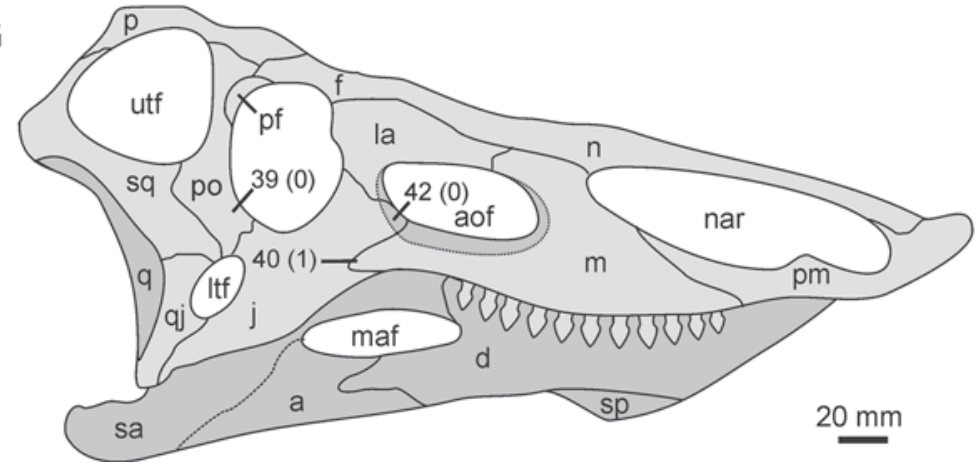

B

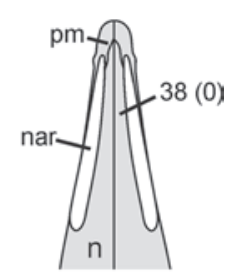

D

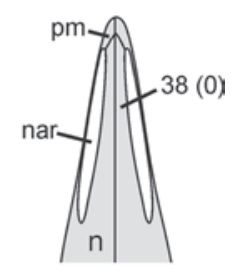

F<smiles>C=CC1CCCCC1C(C)C</smiles>

$\mathrm{H}$

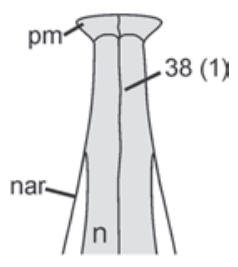

Fig. 7. 


\subsection{Postorbital}

The postorbital is a large triradiate bone, suturing the postfrontal anteriorly, by that contributing to the interorbital bar, and has a small contact with the parietal dorsally (Figs. 3-5). It further forms the anterior and anteroventral margin of the supratemporal fenestra. The ventral process contacts the dorsal wing of the jugal, and also makes a small contribution to the ventral margin of the orbit, similar to most aetosaurs except Desmatosuchus (Fig. 7). Posteriorly, it forms the dorsal margin of the infratemporal fenestra. Posterodorsally, the postorbital has a broad contact with the squamosal through an interlocking suture. Altogether, the ventral process of the postorbital is substantially shorter in Aetosaurus, both are robust, a feature by which both genera differ from other aetosaurs.

\subsection{Jugal}

The jugal differs substantially from that of most aetosaurs. It is more or less rectangular, having a nearly straight dorsal margin, suturing the lacrimal in a short contact, the maxilla in a complicated three-fingered suture, and the postorbital and quadratojugal in small point contacts posteriorly (Figs. 3-6). The jugal forms nearly the complete ventral margin of the orbit and it is not downturned as in Desmatosuchus (Fig. 7), Longosuchus, and Neoaetosauroides. It forms the anterior, convex margin of the infratemporal fenestra. A shallow ridge runs alongside the lateral surface of the bone, paralleling the ventral margin. Consistent with other aetosaurs, the jugal has a posterodorsal process, but in Paratypothorax this is completely covered laterally by the long ventral process of the postorbital.

\subsection{Quadratojugal}

The quadratojugal forms the posteroventral portion of the skull, having the shape of a stout S (Figs. 3-5). Its anterior margin is markedly convex, forming the posterior rim of the infratemporal fenestra. The quadratojugal is dorsally covered by the postorbital and squamosal. In turn, it overlaps the quadrate posteriorly and overhang the articular which lay medial to it when articulated. Below the infratemporal fenestra, the quadratojugal bears a small process that overlaps the jugal. In SMNS 19003, this spike-like process is exposed because of a minor disarticulation of the squamosal and jugal, like in Stagonolepis robertsoni (WALKER 1961). The quadrate foramen is located on the posterior side, next to a shallow depression formed by the quadratojugal and the quadrate.

\subsection{Squamosal}

The squamosal contacts the postorbital by a zig-zag suture and the parietal in a strongly serrated suture. It has a large, markedly convex posterodorsal end and forms the entire ventral margin of the supratemporal fenestra (Figs. 3-5). Its posteroventral part overlaps the quadrate. In contrast to other aetosaurs, the squamosal extends little ventrally, not below the level of the suture with the postorbital. It is unclear whether this is caused by slight displacement of elements in SMNS 19003. The posterior margins of squamosal and parietal forms the paroccipital process, projecting posteriorly to cover the otic region of the quadrate and forming part of the otic synovial joint (see Holliday \& WiTMER 2008). As in Aetosaurus, the squamosal is well separated from the margin of the infratemporal fenestra (Fig. 7).

\subsection{Occiput and braincase}

This region is partially covered by cervical armour and sediment. However, some bones are articulated and exposed lateroventrally (Figs. 3, 6). The basioccipital is visible in lateral view, forming the almost hemispherical occipital condyle, in articulation with the left exoccipital/opisthotic. The occipital condyle is well preserved, separated by a neck from the braincase, its dorsal portion covered by sediment and cervical osteoderms. Laterally to the condyle, the foramen of N. XII is present, bordered by the exoccipital bone, but the suture between this bone and the basioccipital remains unclear. The lateral ridge is formed by the descending process of the exoccipital and extends down to the upper portion of the basioccipital. This region is broken with the result that the metotic foramen and fenestra ovalis are collapsed. A thin slender portion of

Fig. 7. Skulls of selected aetosaurs. A, B - Paratypothorax andressorum (SMNS 19002); C, D - Aetosaurus ferratus (ScHocH 2007); E, F - Stagonolepis robertsoni (WALKeR 1961); G, H - Desmatosuchus smalli (SMALl 2002). 
the prootic is visible close to the otic synovial joint. This bone has a rectangular shape and is overlapped dorsally by the first lateral cervical osteoderm. The otic articular region is formed by the prootic, opisthotic, the otic articular region of the quadrate, and the squamosal. The basioccipital extends anteroventrally and forms part of the basal tubera, consisting of two large ventral protuberances. There remains an unossified cleft between these and the parabasisphenoid tuber, as in the case of Stagonolepis (Gower \& WALKER 2002). Anteriorly, an arched and concave short ventral surface of the parabasisphenoid forms an oval depression (medial pharyngeal recess), close to the basal tubera, and laterally by demarcated by a channel. This probably forms the entrance for the cerebral branch of the internal carotid artery into the braincase. There are four fractures on the anterior part of the parabasisphenoid, one almost tranversal to the anteroposterior axis to the deep depression (or medial pharyngeal recess), a second projecting from this depression anterolaterally to the basipterygoid process, and the other two aligned mainly anteroposteriorly. Anteriorly, the parabasisphenoid projects laterally to form the elongate basipterygoid process. The left basipterygoid process is well preserved and exposes an articular surface, lateral to the basal tubera but at the same level (not ventral as in Batrachotomus). It bears several crests. The basipterygoid process is longer and more slender than in Aetosaurus, and the basal tubera and basioccipital appear shorter than in Aetosaurus, which may result from distortion. Anteriorly, a thin long projection extending anteriorly between the medial region of both pterygoids forms a fragment of the cultriform process, as in other aetosaurs (e.g., Stagonolepis, Neoaetosauroides).

\subsection{Palate}

Almost the complete left side of the palate is visible in ventral view, with only the anteriormost region obscured by the mandibular symphysis (Figs. 3, 6). The palatine is a slender bone that forms the anterior and medial margins of the suborbital fenestra. In Paratypothorax, the medial outline of that window is rectangular. The anterior region of the palatine is covered by the splenial, but the posterior portion projects medially and contacts the pterygoid along the lateral anterior margin. The palatine-pterygoid suture is serrated and extends transversely over the lateral ridge that borders the suborbital fenestra. This condition is similar to Neoaetosauroides but differs from Aetosaurus, where the suture runs lateral to that ridge. The pterygoids were probably in contact along the midline, but this is not preserved. The narrow palatine processes of the pterygoids form a medial tongue-like projection that separates the palatines in the midline. The wing-shaped lateral process of the pterygoid projects ventrally and might have contacted the ectopterygoid anteriorly, but this portion is obscured by the mandible. The proportions of the pterygoid are generally consistent with Aetosaurus, only that the transverse process is stouter and the interpterygoid vacuity still smaller in Paratypothorax. Furthermore, the quadrate process is oriented posteriorly rather than laterally as in Aetosaurus.

\subsection{Mandible}

Both mandible halves are well preserved and articulated. The lower jaw is low and elongate, compared with other aetosaur mandibles, but with a distinctive slipper shape shared only by some aetosaurs, like Desmatosuchus, Stagonolepis, Neoaetosauorides, contrasted by Aetosauroides (Figs. 3-7).

The dentary forms the largest bone, having an edentulous and sharp anterior end, with several small foramina near the dorsal margin. It forms the anterodorsal margin of the external mandibular fenestra. In this region, it bears two distinct processes that form the anterodorsal and ventral margin of that fenestra, with the dorsal process twice the length of the ventral one, as in Aetosaurus and Stagonolepis robertsoni. The latter overlaps the angular and splenial, respectively. A large foramen is located at the level of the premaxilamaxillary contact. It probably housed the mandibular branch of the trigeminal cranial nerve (V) (Fig. 6B).

The splenial (Figs. 5, 6) is a laminar bone that covers the medial surface of the lower jaw. Anteroventrally, the mylohyoid foramen is present close to the symphysis. The posterior region of the splenial is divided in three dorsoventral projections, the largest of which is the medial one. A dorsal projection ovelaps the surangular, whereas a medial one overplates the prearticular.

The prearticular is a slender, dorsomedially curved bone that forms the ventral margin of the internal mandibular fenestra. Anteriorly, it is overlapped by the medial projection of the splenial, and dorsally covered by the pterygoid wing. Ventrally, the prearticular sutures with the angular, and posterodorsally it projects with a thin lamina to form the posterior margin of the internal mandibular fenestra. The angular is a long slender bone that forms more than one third of the ventral margin of the mandible.

Laterally, the angular forms the complete ventral 
margin of the external mandibular fenestra, contacting the surangular with an oblique suture. The surangular (laterally) and prearticular (medially) both overlap the angular. The surangular is laterally well exposed, with its anterior region forming the posterior margin of the mandibular fenestra. The surangular foramen is located close to the glenoid cavity on the lateral surface of the surangular. Posteroventrally, this bone forms the lateral and ventral part of the retroarticular process. The articular is visible only in the left mandible half, rising mediodorsally from the surangular to form a thornlike retroarticular process. This process resembles the articular projection of Stagonolepis and Aetosaurus.

\subsection{Dentition}

The premaxilla, maxilla, and dentary throughout bear recurved and slightly bulbous teeth that are implanted in thecodont fashion. There are no wear facets, no clear carinae, and serrations are absent throughout. There are four teeth in the premaxilla, as exposed on the left side. On the right side only the posteriormost premaxillary tooth is preserved, close to the suture with the maxilla. The premaxillary teeth are a somewhat smaller than those of the maxilla and dentary, with a small neck between the root and crown. The maxillary teeth are well preserved, with 6 on the left side and 10 on the right. The anterior teeth are somewhat better exposed, with the root partially outside the theca. There is a slight constriction between the root and crown. The crown is bulbous but the general shape of tooth is gently recurved. There are some fine striations on the crown. There are ten alveoli in situ.

The presence of interdental plates cannot be ascertained because the upper and lower mandibles are articulated. Only two teeth on the right dentary are exposed. There is a marked diastema between the last premaxillary tooth and the first maxillary tooth.

\subsection{Hyobranchial elements}

Two elements of the hyoid skeleton occur in articulation with the medial side of the lower jaw (Figs. 5-6). As in Aetosaurus, they form slightly curved rods with an expanded and flat blunt anterior end. In Paratypothorax, they are markedly stouter. These bones might be homologous to the first ceratobranchials, which probably articulated with a cartilaginous corpus hyoideum. There is a groove along the dorsal surface of these elements, indicating the presence of a cartilaginous cover.

\subsection{Cervical osteoderms}

The first two rows of cervical osteoderms articulate with the skull. The first row is formed by small and slender paramedian osteoderms that gently overlap the posterior margin of the occipital slope of the parietal. These osteoderms contact along the midline and are 26 $\mathrm{mm}$ wide and $10 \mathrm{~mm}$ long. They have rounded margins, without an anterior articular bar and no pair of lateral osteoderms. In contrast, the second row of cervical osteoderms includes a large rectangular paramedian (30 $\mathrm{mm}$ wide and $13.5 \mathrm{~mm}$ long) with an anterior articular bar and a tiny, rounded of lateral osteoderms $(16 \mathrm{~mm}$ wide and $8 \mathrm{~mm}$ long). All subsequent osteoderms on the cervical region are consistent with the condition in Aetosaurus.

\section{Phylogenetic analysis}

The description of the skull in SMNS 19003 has revealed numerous cranial features that add to our knowledge of Paratypothorax andressorum, as well as aetosaur skull anatomy in general. The bearing of these features on aetosaur phylogeny formed the scope of a cladistic analysis. It addressed the following questions: (1) is the referral of SMNS 19003 to Paratypothorax andressorum, based on diagnostic characters of the paramedian plates, supported cladistically; (2) who are the closest relatives of Paratypothorax, and (3) what is the impact of the new findings on aetosaur phylogeny as a whole?

To this end, a cladistic analysis was performed in which SMNS 19003 was added as a separate OUT to the data matrix of DA SiLva et al. (2014), which was based on the original matrix of PARKER (2007). The resulting data matrix is composed of 44 characters and 23 taxa. The first 37 characters were adopted from $D_{A}$ SiLva et al. (2014) and the other seven (38 to 44) are new cranial features identified and coded by us (see Appendix).

The data matrix was analyzed under equally weighted maximum parsimony using TNT 1.1 (GoLoBOFF et al. 2008) in which we performed an analysis under traditional search of 50 replications of Wagner trees (with random addition sequence), followed by the TBR branch swapping algorithm (holding 10 trees per replicate), was performed. Zero length branches among any of the recovered MPTs were collapsed (i.e. rule 1 of Coddington \& ScharfF [1994]), ACCTRAN mode. The main analysis found 9 most parsimonious trees, requiring 95 steps. In this analysis, Coahomasuchus turned out to be a wild card taxon. Its removal (variant 


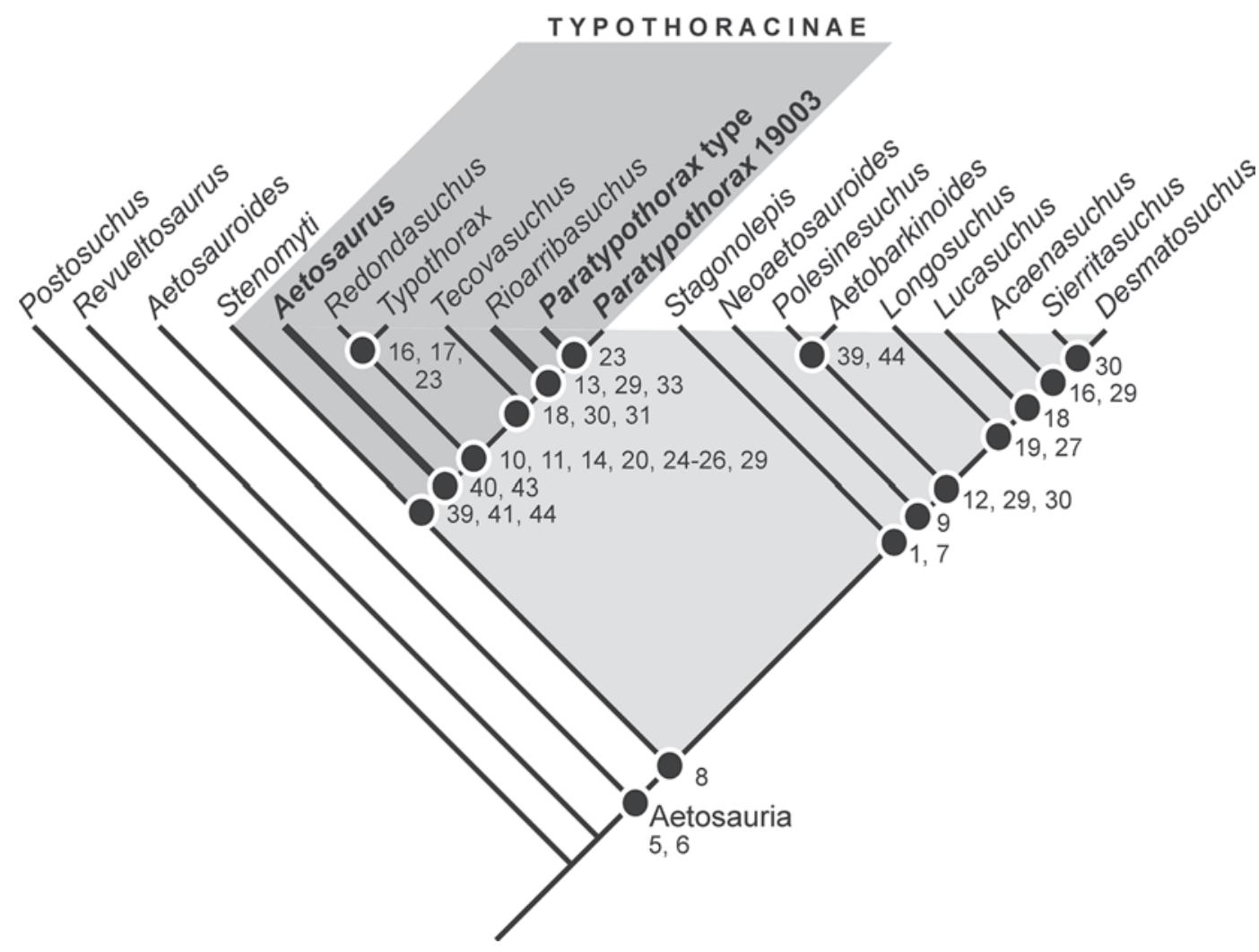

Fig. 8. Cladogram as found by the present phylogenetic analysis. Numbers refer to characters supporting a given node.

analysis) gave a clearly better resolved topology (one tree, see below and Fig. 8).

General results. In both analyses, SMNS 19003 and the type specimen of Paratypothorax andressorum were found to be "sister taxa". We take this as evidence that corroborates the referral of SMNS 19003 to $P$. andressorum, rather than erect a new taxon for which we find no unambiguous unique characters. In the following discussion, we therefore refer to both SMNS 19003 and the type specimen when speaking of Paratypothorax.

Main analysis (23 taxa, 44 characters): In this poorly resolved topology, Aetosauroides forms the basalmost aetosaur. All other taxa fall onto a polytomy consisting of the following taxa: (1) Stenomyti, (2) Neoaetosauroides, (3) Coahomasuchus, (4) Aetosaurus, (5) Stagonolepis (2 species), (6) Typothoracinae, and (7) Desmatosuchinae. Notably, Paratypothorax firmly nests within the Typothoracinae, forming the sister taxon of Rioarribasuchus. The relationships within Typothoracinae and Desmatosuchinae are the same as in the variant analysis, whose topology is depicted in Fig. 8.

Variant analysis (22 taxa, 44 characters): The exclusion of Coahomasuchus results in the topology to be fully resolved, and the two genera Aetosaurus and Stenomyti forming basal members of the Typothoracinae. The other nodes are the same as in the main analysis. In contrast to the main analysis, Aetosauria falls into three main taxa: (1) the basalmost genus Aetosauroides, (2) the Typothoracinae and (3) Desmatosuchinae. The Typothoracinae include the following taxa, listed from base to crown: Stenomyti, Aetosaurus, Redondasuchus +Typothorax, Tecovasuchus, Paratypothorax and Rioarribasuchus. The sister taxon of Typothoraciscinae and largest aetosaur clade, the Desmatosuchinae, encompasses the following successive sister groups: Stagonolepis (2 species), Polesinesuchus + Aetobarbakinoides, Longosuchus, Lucasuchus, Acaenasuchus, Sierritasuchus and Desmatosuchus (2 species). In a second variant analysis, we omitted character 29 , which was questioned by former authors; this gave the 
same topology as in the variant analysis of the full set of characters.

Considering the poor knowledge of the skull in Coahomasuchus, its small size, thinner plates and the faint ornamentation, along with a general similarity to Stenomyti and Aetosaurus, we consider this taxon to represent the juvenile of an aetosaur of which the adult remains unknown. Therefore, we base the following discussion on the results of the variant analysis, which appears to us a more cautious approach.

Unlike Coahomasuchus, Stenomyti forms an essential taxon to stabilize the topology of basal aetosaurs. Its removal results in a polytomy of the basal aetosaur taxa, but Aetosaurus remains at the base of the Typothoracinae.

\subsection{Aetosaurus and Paratypothorax - growth stages or separate taxa?}

The most surprising result of the present study is the close resemblance of the skull in Paratypothorax and Aetosaurus. Its bearing on the ingroup phylogeny of aetosaurs appears to be profound: our cladistic analysis indicates a closer relationship between these two taxa than was hitherto found. Although they do not form sister taxa, they are the single two taxa of the whole clade for the which the skull anatomy is well known; their placement in different nodes within the Typothoracinae may well be influenced by differences in plate morphology - a set of characters that were evidently subject to ontogenetic changes at least within the Aetosaurus sample (Sсносн 2007). Ontogeny therefore cannot be ignored when analyzing aetosaur relationships. Skeletochronology has recently added to this picture: Aetosaurus from Kaltental was clearly a juvenile aged maximally one year, whereas the type specimen of Paratypothorax from Heslach was at least 17 years old (TABORDA et al. 2013; SChEYER et al. 2014). This urges us to address a new and rather heretical question: could it be that Aetosaurus forms the juvenile of Paratypothorax?

We are fully aware that this question may not be satisfactorily answered with the currently available sample, as there remains a major gap between the largest Aetosaurus and smallest Paratypothorax specimens. From a purely morphological view, the most striking differences between Paratypothorax and Aetosaurus are the greater proportional width of paramedian osteoderms in Paratypothorax and the more excessive development of dorsal eminences and ornamentation. In addition, the presence of spikes on lateral osteoderms of Paratypothorax differs with the thin eminence on lateral osteoderms of Aetosaurus. These differences may be due to taxonomy or ontogeny. Given that histological sections on lateral osteoderms (work in progress) might shed more light on the early development of the structure on the external cortex of the dermal bone.

Aetosaurus and Paratypothorax are the only aetosaurs to occur in the Middle Norian of Germany, and both taxa are found in the Lower and Middle Stubensandstein members of the Löwenstein Formation. This co-occurrence is consistent with the hypothesis of taxonomic identity, but of course not a sufficient criterion. However, morphology and skeletochronology also add to this picture. Even at closer sight, Aetosaurus does not appear to have autapomorphies that would render it different from Paratypothorax. The two most clearcut differences, the maxilla tooth count and shape of the supratemporal fenestra, may both be linked to changes in ontogeny. Accepting the above cited skeletochronological data, the currently known morphology of Aetosaurus should be considered as immature. The question then emerges whether (1) Aetosaurus forms the juvenile of a close relative of Paratypothorax (such as suggested by the present cladistic analysis) or (2) Aetosaurus itself forms the juvenile of Paratypothorax.

\subsubsection{Growth stages hypothesis}

There are numerous close similarities between Aetosaurus and Paratypothorax consistent with the hypothesis that both belong to the same taxon. Shared features include the identical morphology of the unexpanded, eagle-shaped beak, the region of the antorbital fossa, the ventrally straight jugal, the number of cervical and dorsal osteoderms as well as the position of the 'wasp waist' anterior to the pelvic region (Fig. 2G; SсHOCH 2007).

Conversely, the following features differ between Aetosaurus and Paratypothorax, but may be the result of allometry.

(1) Dermal bones are proportionally much thinner in Aetosaurus, and they are still substantially thinner in SMNS 19003 as compared to the type of Paratypotho$\operatorname{rax}$ (SCHEYER et al. 2014).

(2) Ornament is absent or gentle in Aetosaurus, and grooves on medial skull roof shallow and discontinuous, contrasted by very pronounced and regionally differentiated ornament and profound, continuous grooves in Paratypothorax.

(3) Sutures are relatively simple in Aetosaurus and easier to trace than in Paratypothorax where they are more serrated. 
(4) The retroarticular process is longer and taller in Paratypothorax, suggesting a larger depressor muscle to have attached, consistent with an ontogenetic increase in muscle mass.

(5) The parietal is longer in small Aetosaurus specimens, almost reaching the length of the frontal, but proportionally shorter in larger Aetosaurus and Paratypothorax.

(6) There may have been a pineal foramen in Aetosaurus (not described by $\mathrm{S}_{\mathrm{CHOCH}}$ 2007), which is definitely absent in Paratpothorax. Ontogenetic closure of the pineal foramen does occur in tetrapods $\left(\mathrm{S}_{\mathrm{CHOCH}} \&\right.$ MiLner 2014).

(7) The parabasisphenoid is longer in small Aetosaurus, correlating with a longer parietal in juveniles.

(8) SMNS 19003 is as much 'waisted' anterior to the pelvis as is Aetosaurus; this has not been reported or reconstructed in the much larger type specimen of Paratypothorax, but remains unclear due to disarticulation of that material.

(9) The spikes on lateral osteoderms are very pronounced in the type specimen, but less developed in SMNS 19003, and absent in Aetosaurus.

(10) Evidently, the paramedian osteoderms are much wider (width:length ratio) in Paratypothorax than in Aetosaurus. Whereas the two specimens of Paratypothorax do not differ in this trait, the width of the dorsal paramedian osteoderms is clearly size-linked in Aetosaurus ( $\mathrm{S} \mathrm{CHOCH}$ 2007). This suggests that the juveniles of other aetosaurs, such as Typothorax and desmatosuchines, probably had similar slender body outlines as Aetosaurus.

\subsubsection{Separate taxa hypothesis}

The present taxonomic problem might be resolved when autapomorphies of one of the two taxa were identified. Optimally, these should not be restricted to certain ontogenetic stages. However, the major gap in morphology and size between all specimens of Aetosaurus and Paratypothorax render such an identification difficult. The following features rank among the most clear-cut differences between Aetosaurus and Paratypothorax. (1) The tooth count of the maxilla and dentary is variable in Aetosaurus ( $\mathrm{S} \mathrm{CHOCH} 2007)$, whereas in Paratypothorax only one skull is known. Whereas the maxilla tooth count in Aetosaurus (8-9) overlaps with that of Paratypothorax (9), that of the dentary does not (Aetosaurus: 7-8, Paratypothorax: 9). This picture, of course, may change with deepened knowledge of variation in Paratypothorax, and the point is also weakened by the fact that the mandibular tooth count is difficult to assess in most specimens of Aetosaurus $(\mathrm{SCHOCH}$ 2007).

(2) In Paratypothorax the supratemporal fenestra is triangular, correlating with a much shorter parietal. In Aetosaurus, the fenestra is rounded and proportionally much larger than in Paratypothorax. Because the condition in Aetosaurus is consistent with that of adult Stagonolepis and Neoaetosauroides, it appears unlikely that the condition in Paratypothorax simply represents the adult morphology. Instead, it appears to form an apomorphic state for that taxon. However, this argument is somewhat weakened by individual variation in Aetosaurus as documented by $\mathrm{S} \mathrm{CHOCH}$ (2007), where outlines range from wide oval to triangular, the latter forming a rare condition

(3) In Paratypothorax, the upper jaw margin has a deep notch between premaxilla and maxilla, which is not found in Aetosaurus.

(4) The orbit houses three articulating supraorbital elements in Aetosaurus, which is shared with Stenomyti. In Paratypothorax, there appears to be only one small such element. However, this character needs to be considered with caution, because these small bonelets may easily have been disarticulated and lost before final burial of the skull.

\section{Conclusion}

From a purely cladistic perspective, Paratypothorax and Aetosaurus appear to be distant relatives within the same clade. However, the present analysis - as all cladistic aetosaur analyses before - is not well supported by robust characters and plagued by a large faction of missing data. In addition, the finding that the known Aetosaurus specimens were juvenile raises an issue well known to students of groups in which ontogeny has a significant impact on phylogeny. As WiENs et al. (2004) put it, "ontogeny" may "discombobulate phylogeny" in that taxa with immature morphology (or fossil taxa of which only immature specimens are known) may group together in a phylogeny, apart from the adults. This matches the present finding quite precisely, in that the taxa with juvenile appearance (Aetosaurus and Stenomyti) nest at the base of a clade otherwise only represented by taxa known from adult specimens only. In such a case, cladograms should be interpreted with still greater caution than normally required.

Considering the aforementioned problems, it is also possible that Aetosaurus and Paratypothorax form the end points of a growth series, considering that (1) 
they co-occur in the same formations, (2) there are no strong autapomorphies in either form distinguishing the two from one another, (3) the type of Aetosaurus was clearly immature (<one year) contrasted by the type of Paratypothorax which was clearly adult ( $>17$ years), and (4) the observed ontogenetic changes in both the Aetosaurus and Paratypothorax samples indicate that the region of major morphological differences (trunk osteoderms) underwent consistent ontogenetic changes in both taxa (increase in paramedian osteoderm width and allometric growth of eminences and spikes).

However, we maintain a cautious approach here because evidence is ambiguous. Although some of the most important features distinguishing Aetosaurus from Paratypothorax were size-linked, it cannot be ruled out that Aetosaurus may have been the juvenile of a close relative of Paratypothorax of which the adult morphology remains unknown. This cautious view is prompted by the fact that cladistic analysis finds Aetosaurus to nest in a grade with Stenomyti at the base of the clade, whereas Paratypothorax nests with Rioarribasuchus more crownwards within Typothoracinae. However, the skull of Typothorax differs clearly in some key features from both Aetosaurus and Paratypothorax, indicating conflicting evidence with osteoderm characters. Palaeohistology and further preparation of SMNS 19003, along with computer tomography of both Aetosaurus and Paratypothorax specimens, may help to resolve this taxonomic problem.

Aetosaurs probably underwent a profound change in ontogeny, with juveniles bearing narrower osteoderms, lacking spikes, having simple sutures and a faint ornament. Paratypothorax is now known with a very well-preserved skull, which differs substantially from that of many aetosaurs, while closely resembling that of Aetosaurus and (to a lesser degree) Stenomyti, formerly considered only distant relatives falling on a basal grade of aetosaurs. At the same time, the skull of Paratypothorax differs from that of Typothorax, which for instance has a shovel-like tip of snout, although the overwhelming majority of osteoderm characters suggest that Paratypothorax and Typothorax are closely related.

This, in turn, indicates problems with our previous understanding of characters. Juvenile features of aetosaurs, characterizing Aetosaurus, Stenomyti, and probably Coahomasuchus, have been interpreted as plesiomorphic traits, with the result that these juvenile forms were found to nest (among others) with truly basal taxa such as Aetosauroides (PARKer 2007; PARKer et al. 2008).
Further studies of aetosaur ontogeny and histology may eventually lead to a more profound understanding of a fascinating Triassic clade of archosaurs, which departs so boldly from the carnivorous archosaur mainstream and whose ontogeny involved interesting patterns not known from other extinct clades of the group.

\section{Acknowledgements}

We thank ACHIM LeHMKuhl and Norbert Adorf for their meticulous and patient preparation of SMNS 19003. DIETER SEEGIS provided much helpful first-hand stratigraphic information on the Middle Keuper. This research was partially funded by the Agencia Nacional de Promocion Cientıfica y Tecnica PICT 2012 No. 925 and Alexander von Humboldt Foundation (to J.B.D.). The two anonymous reviewers and the journal's editor GüNTER SCHWEIGERT are thanked for their critical and constructive reviews.

\section{References}

Berckhemer, F. (1949): Zugänge. Geologische Abteilung. Jahreshefte des Vereins für vaterländische Naturkunde in Württemberg, 97-101: XLII-XLVI.

Brenner, K. (1978): Profile aus dem Oberen Mittelkeuper Südwest-Deutschlands. - Arbeiten aus dem Institut für Geologie und Paläontologie der Universität Stuttgart, Neue Folge, 72: 103-203.

Casamiquela, M. (1960): Notica preliminar sobre dos nuevos estagonolepoideos Argentinos. - Ameghiniana, 2: 3-9.

Coddington, J. \& ScharfF, N. (1994): Problems with zerolength branches. - Cladistics, 10: 415-423.

Cope, E.D. (1869): Synopsis of the extinct Batrachia and Reptilia of North America. - Transactions of the American Philosophical Society, 14: 1-252.

Da Silva, R., Desojo, J.B., Cabeira, S.R.F., Aires, A.S.S., Müller, R.T., Pacheco, C.P. \& Dias-DA-Silva, S.R. (2014): A new aetosaur from the Upper Triassic of the Santa Maria Formation, southern Brazil. - Zootaxa, 3764: 240-278.

Desojo, J.B. \& Heckert, A.B. (2004): New information on the braincase and mandible of Coahomasuchus (Archosauria: Aetosauria) from the Otischalkian (Carnian) of Texas. - Neues Jahrbuch für Geologie und Paläontologie Monatshefte, 2004: 605-616.

Desojo, J.B. \& BÁEz, A.M. (2007): Cranial morphology of the Late Triassic South American archosaur Neoaetosauroides engaeus: evidence for aetosaurian diversity. - Palaeontology, 50: 267-276.

Desojo, J.B. \& Vizcaino, S.F. (2009): Jaw biomechanics in the South American aetosaur Neoaetosauroides engaeus. - Paläontologische Zeitschrift, 83: 499-510.

Desojo, J.B. \& Ezcurra, M.D. (2011): A reappraisal of the taxonomic status of Aetosauroides (Archosauria, Aetosauria) specimens from the Late Triassic of South America and their proposed synonymy with Stagonolepis. - 
Journal of Vertebrate Paleontology, 31: 596-609.

Desojo, J.B., Heckert, A.B., Martz, J.W., Parker, W.G., Schoch, R.R., Small, B.J. \& SuleJ, T. (2013): Aetosauria: a clade of armoured pseudosuchians from the Late Triassic continental beds. - In: Nesbitt, S.J., Desojo, J.B. \& Irmis, R.B. (eds.): Anatomy, Phylogeny and Palaeobiology of Early Archosaurs and their Kin. - Geological Society, London, Special Publications, 379: 203-239.

Etzold, A. \& Schweizer, V. (2005): Der Keuper in BadenWürttemberg. - Courier Forschungsinstitut Senckenberg, 253: 214-258.

FraAs, O. (1877): Aëtosaurus ferratus Fr. Die gepanzerte Vogel-Echse aus dem Stubensandstein bei Stuttgart. Festschrift zur Feier des vierhundertjährigen Jubiläums der Eberhard-Karls-Universität zu Tübingen. - Jahresheftes des Vereins für vaterländische Naturkunde in Württemberg, 33: 1-22.

Gauthier, J.A. \& Padian, K. (1985): Phylogenetic, functional, and aerodynamic analyses of the origin of birds and their flight. - In: Ostrom, J.H., Нecht, M.K., Viohl, G. \& Wellnhofer, P. (eds.): The beginning of birds: 185-197; Eichstätt (Freunde des Jura-Museums).

GolobofF, P.A., FARris, J.S. \& Nixon, K.C. (2008): TNT, a free program for phylogenetic analysis. - Cladistics, 24: 774-786.

Gower, D.J. \& WALKer, A.D. (2002): New data on the braincase of the aetosaurian archosaur (Reptilia: Diapsida) Stagonolepis robertsoni Agassiz. - In: Norman, D.B. \& Gower, D.J. (eds.): Archosaurian Anatomy and Paleontology. - Zoological Journal of the Linnean Society, 136: $7-23$.

Gregory, J.T. (1953): Typothorax and Desmatosuchus. - Postilla, 16: 1-27.

Heckert, A.P. \& Lucas, S.G. (1999): A new aetosaur (Reptilia: Archosauria) from the Upper Triassic of Texas and the phylogeny, biochronology, and paleobiogeography of aetosaurs. - Journal of Vertebrate Paleontology, 19: 50-68.

Heckert, A.P. \& Lucas, S.G. (2000): Taxonomy, phylogeny, biostratigraphy, biochronology, paleobiogeography, and evolution of the Late Triassic Aetosauria (Archosauria: Crurotarsi). - Zentralblatt für Geologie und Paläontologie, 2000 (11-12): 1539-1587.

Heckert, A.B., Lucas, S.G., Rinehart, L.F., Celeskey, M.D., Spielmann, J.A. \& Hunt, A.P. (2010): Articulated skeletons of the aetosaur Typothorax coccinarum CoPE (Archosauria: Stagonolepididae) from the Upper Triassic Bull Canyon Formation (Revueltian: early-mid Norian), eastern New Mexico, USA. - Journal of Vertebrate Paleontology, 30: 619-642.

Holliday, C.M. \& Witmer, L.M. (2008): Cranial kinesis in dinosaurs: intracranial joints, protractor muscles, and their significance for cranial evolution and function in diapsids. - Journal of Vertebrate Paleontology, 28: 10731088.

HungerbüHLER, A. (2002): The Late Triassic phytosaur Mystriosuchus westphali, with a revision of the genus. - Palaeontology, 45: 377-418.

Jalil, N., LuCAS, S.G. \& Hunt, A.P. (1995): Biochronological significance of aetosaurs and phytosaurs (Reptilia, Archosauromorpha) in the Triassic Zarzaïtine Series of
Algeria. - Neues Jahrbuch für Geologie und Paläontologie, Monatshefte, 1995: 173-181.

KutTy, T.S. \& Sengupta, D.P. (1989): The Late Triassic formations of the Pranhita-Godavari Valley and their vertebrate faunal succession-a reappraisal. - Indian Journal of Earth Sciences, 16: 189-206.

LoNG, R.A. \& BALLEw, K.L. (1985): Aetosaur dermal armor from the Late Triassic of southwestern North America, with special reference to material from the Chinle Formation of Petrified Forest National Park. - Museum of Northern Arizona Bulletin, 47: 45-68.

LucAs, S.G. (2000): Pathological aetosaur armor from the Upper Triassic of Germany. - Stuttgarter Beiträge zur Naturkunde, (B), 281: 1-6.

Marsh, O.C. (1884): The classification and affinities of dinosaurian reptiles. - Nature, 31: 68-69.

Martz, J.W. \& SMall, B.J. (2006): Tecovasuchus chatterjeei, a new aetosaur (Archosauria: Aetosauria) from the Tecovas Formation (Upper Triassic, Carnian) of Texas. - Journal of Vertebrate Paleontology, 26: 308-320.

Meyer, H. v. (1861): Reptilien aus dem Stubensandstein des oberen Keupers. - Palaeontographica, 7: 253-346.

Meyer, H. v. (1865): Reptilien aus dem Stubensandstein des oberen Keupers (Dritte Folge). - Palaeontographica, 7: 253-346.

PARKer, W.G. (2007): Reassessment of the aetosaur "Desmatosuchus" chamaensis with a reanalysis of the phylogeny of the Aetosauria (Archosauria: Pseudosuchia). - Journal of Systematic Palaeontology, 5: 1-28.

PARKer, W.G. (2008): Description of new material of the aetosaur Desmatosuchus spurensis (Archosauria: Suchia) from the Chinle Formation of Arizona and a revision of the genus Desmatosuchus. - PaleoBios, 28: 281-340.

Parker, W.G., Irmis, R.B., Nesbitt, S.J., Martz, J.W. \& Browne, L.S. (2005): The Late Triassic pseudosuchian Revueltosaurus callenderi and its implications for the diversity of early ornithischian dinosaurs. - Proceedings of the Royal Society, (B), 272: 963-969.

PARrish, J.M. (1994): Cranial osteology of Longosuchus meadei and the phylogeny and distribution of the Aetosauria. - Journal of Vertebrate Paleontology, 14: 196-209.

SAwin, H.J. (1947): The pseudosuchian reptile Typothorax meadei. - Journal of Paleontology, 21: 201-238.

Scheyer, T., Desojo, J.B. \& Cerda, I. (2014): Bone histology of phytosaur, aetosaur, and other archosauriform osteoderms (Eureptilia, Archosauromorpha). - Anatomical Record, 297: 240-260.

ScHoch, R.R. (2007): Osteology of the small archosaur Aetosaurus from the Upper Triassic of Germany. - Neues Jahrbuch für Geologie und Paläontologie, Abhandlungen, 246: $1-35$.

Schoch, R.R. \& Milner, A.R. (2014): Temnospondyli. - In: Sues, H.D. (ed.): Encyclopedia of Paleoherpetology, 3A2: 1-160; Munich (Pfeil).

SEEGIS, D. (1986): Unsere Heimat zur Stubensandstein-Zeit. Heimatblätter. Jahrbuch für Schorndorf und Umgebung, 4: $88-108$

SEEgIS, D. (2005): Tetrapoden. - Courier Forschungsinstitut Senckenberg, 253: 50-54.

Small, B.J. (2002): Cranial anatomy of Desmatosuchus haplocerus (Reptilia: Archosauria: Stagonolepididae). - 
Zoological Journal of the Linnean Society, 136: 97-111.

Small, B.J. \& Martz, J.W. (2013): A new basal aetosaur from the Upper Triassic Chinle Formation of the Eagle Basin, Colorado, USA. - In: NesBitt, S.J., Desojo, J.B. \& Irmis, R.B. (eds.): Anatomy, Phylogeny and Palaeobiology of Early Archosaurs and their Kin. - Geological Society of London, Special Publications, 379: 393-412.

Taborda, J.R.A., Cerda, I.A. \& Desojo, J.B. (2013): Growth curve of Aetosauroides scagliai CASAmiQuela 1960 (Pseudosuchia: Aetosauria) inferred from osteoderm histology. - Geological Society of London, Special Publications, 379: 413-423.

Walker, A.D. (1961): Triassic reptiles from the Elgin area: Stagonolepis, Dasygnathus, and their allies. - Philosophical Transactions of the Royal Society of London, (B), 248: 103-204.

Wiens, J.J., Bonett, R.M., Chippindale, P.T. \& Anderson, F. (2004): Ontogeny discombobulates phylogeny: paedomorphosis and higher-level salamander relationships. - Systematic Biology, 54: 91-110.

Zittel, K.A. (1890): Handbuch der Palaeontologie. 1. Abtheilung: Palaeozoologie, $3^{\text {rd }}$ vol. Vertebrata (Pisces, Amphibia, Reptilia, Aves). Berlin (Oldenbourg).
Manuscript received: November 10th, 2015.

Revised version accepted by the Stuttgart editor: November 19th, 2015.

\section{Addresses of the authors:}

RaIner R. Schoch, Staatliches Museum für Naturkunde Stuttgart, Rosenstein 1, 70191 Stuttgart, Germany: e-mail:rainer.schoch@smns-bw.de

Julia B. Desojo, CONICET, Comisión Nacional de Investigación Científica y Técnica, Sección Paleontología Vertebrados, Museo Argentino de Ciencias Naturales 'Bernardino Rivadavia', Av. Angel Gallardo 470, C1405DJR, Buenos Aires, Argentina;

e-mail: julideso2@gmail.com 


\section{Appendix - Character list}

1. $\quad$ Premaxilla morphology. Anterior end tapering (0); mediolaterally expanded in a shovel-like shape (1). (modified from Parrish, 1994:3; Heckert and Lucas, 1999) Parker (2007: 1).

2. Dentition. Teeth mediolaterally compressed and recurved (0), teeth bulbous and conical with recurved tips (1), teeth bulbous and conical with straight tips (2).

3. $\quad$ Dentary teeth. Anterior part of the dentary with teeth (0) or edentulous (1).

4. $\quad$ Premaxilla dentition. Present, reaching the anterior tip of the alveolar margin (0); present, but the premaxilla is anteriorly edentolous (1); completely absent (2). (modified from Parrish, 1994: 3)

5. External nares. Shorter than (0) or longer than (1) antorbital fenestra.

6. $\quad$ Supratemporal fenestra. Dorsally exposed (0) or lateral (1).

7. Jugal. Not downturned (0) or downturned (1). Ventral margin either straight horizontal (0), or sloping posteroventrally (1), or strongly downturned, aligned at $45^{\circ}(2)$.

$8 . \quad$ 'Slipper-shaped' mandible. Absent (0) or present (1).

9. $\quad$ Dentary tooth count. Nine or more (0) or fewer than nine (1).

10. Transverse processes of dorsal vertebrae. Short, less than twice as wide as the centrum (0) or elongate, buttressed ventrally (1).

11. Presacral neural spine. High (0) or generally low, less than height of centrum (1).

12. Cervical centra. Keeled ventrally (0) or unkeeled (1).

13. Anterior bars on dorsal and lateral osteoderms. Absent (0), weakly raised bar (1), strongly raised bar (2).

14. Width to length ratio of widest dorsal paramedian osteoderms. Maximum of less than 3.5/1 (0), 3.5/1 or more (1).

15. Shape of cervical dorsal paramedian osteoderms. Wider than long (0) or longer than wide (1).

16. $\quad$ Patterning of paramedian osteoderms. Radiate (0) or random (1).

17. Ornamentation of paramedian osteoderms. Consists of mixture of pits, elongate pits, grooves and ridges (0) or small subcircular pits only (1).

18. Dorsal eminence. Contacts posterior margin of the paramedian osteoderms majority of the time (0) or almost never (1).

19. Raised dorsal eminence on cervical and anteriormost paramedian osteoderms. Absent (0), present (1).

20. $\quad$ Ventral keel or strut. Never present (0) or present (1) on some or all paramedian osteoderms.

21. Cervical paramedian osteoderms. Dorsoventrally thickened with tongue-and-groove articulations: no (0) or yes (1).

22. Lateral cervical armour. Lacks (0) or possesses (1) spikes or horns, that may be extremely elongate (2). This character is polymorphic in Paratypothorax where half-grown specimens have state 0 , adults state 1 .

23. Flexure of presacral paramedian osteoderms. None or minimal (0), strongly flexed ventrally (1).

24. Lateral osteoderms. Minimum angle of flexion between the dorsal and lateral flanges of the lateral osteoderms: obtuse (0), approximately $90^{\circ}(1)$, or strongly acute (2).

25. Middorsal lateral osteoderms. Symmetry of dorsal and lateral flanges of middorsal lateral osteoderms: symmetrical (0), asymmetrical with dorsal flange longest (1), asymmetrical with lateral flange longest (2). We recoded the states in Aetosaurus $(0>2)$, Neoaetosauroides $(0>2)$, Paratypothorax $(2>1)$.

26. Narrow region ('waist') in the carapace anterior to the sacrum. Present (0) or absent (1). We recoded the states in Paratypothorax $(1>0)$.

27. Fusion of last presacral vertebra into sacrum. Does not occur (0) or occurs (1).

28. Pelvic and anterior caudal lateral osteoderms. Roughly equant in width and length and possessing a sharp medially situated keel (0), or roughly triangular in lateral view with a semicircular ventrolateral border and a hook-like eminence (1) or rectangular and ventral to a well-developed spine (2).

29. Dorsal eminence on paramedian osteoderms. Centralized (0), moderately offset medially (1) or strongly offset medially (2).

30. Lateral spikes in anterior and mid-dorsal regions. Not present (0), form a dorsoventrally flattened 'horn' (1) or form a conical spine (2).

31. Number of ventral osteoderm rows. 10 or more (0), less than 10 (1).

32. Dorsal eminences on posterior paramedian osteoderms. In the form of a low pyramid or knob (0) or an elongate spine (1).

33. Cervical vertebrae. Extremely shortened anteroposteriorly: no (0) or yes (1).

34. $\quad$ Posterior margin of paramedian osteoderms. Strongly bevelled: no (0) or yes (1).

35. Cervical lateral osteoderms of the sixth row. Extremely enlarged: no (0) or yes (1).

36. Dorsal flange of dorsal lateral osteoderms. Rectangular (0), broadly triangular (1) or tongue-shaped (2).

37. Mound-like dorsal eminences on anterior dorsal lateral osteoderms. Absent (0) or present (1) 


\section{Additional characters}

38. $\quad$ Nasal. Tapering towards tip (0), or throughout of equal width (1). See Fig. 7B, D (0) and F, H (1).

39. Postorbital. Confined to posterior orbit margin (0), or ventral extended to form part of the ventral orbit margin (1). See Fig. 7 A, C (1) and E, G (0).

40. Maxilla. Posterior end sutures broadly with jugal (0), or downcurved and with three separate finger-like processes (1). See Fig. 7A, C (1) and E, G (0).

41. Maxilla-Lacrimal. Suture more or less straight or irregular (0), or with finger-like process of maxilla (1). See Fig. 7A, C (1) and E, G (0).

42. Antorbital fossa. With jugal contribution (0), or formed by the maxilla and lacrimal only, excluding jugal from the margin of the antorbital fenestra (1). See Fig. 7A, C (1) and E, G (0).

43. Infratemporal fenestra. Squamosal enters infratemporal margin (0), or excluded by postorbital-quadratojugal contact (1). See Fig. 7A, C (1) and E, G (0).

44. Palpebral bones. Such extra ossifications in the upper eyelid are absent in the primitive condition (0), and in the derived conditions either a single element is present (1), or three such elements are aligned in a parasagittal row, firmly sutured (2).

\section{Character-taxon matrix}

\begin{tabular}{|c|c|}
\hline Postosuchus & 00000000000000-00--0---0--01-0--00----0000000 \\
\hline Revueltosaurus & 02000000?00020011-000-0--10--0--00---?000100 \\
\hline Aetosaurus & $01111101000 ? 20000000000002000100000000111112$ \\
\hline Stagonolepis robertsoni & 12101111000020000000001002000100000000000000 \\
\hline Stagonolepis wellesi & $1 ? ? ? 1 ? 1 ? ? 00020000001001002000100000000000 ? ? ?$ \\
\hline Aetosauroides & ?0??11?0000020000000000002000101000000??0??0 \\
\hline Coahomasuchus & ??1????1???02000000?000002000100000000?????? \\
\hline Desmatosuchus haplocerus & $12121121 ? 0110011011012011111222 ? 000101000000$ \\
\hline Desmatosuchus smalli & $1212112110110011011012011111222 ? 000101000 ? ? 0$ \\
\hline Rioarribasuchus & ????????????11000100?10221?1221?100120?????? \\
\hline Longosuchus & $1211112110012010001012011111102 ? 000000 ? 001 ? 0$ \\
\hline Lucasuchus & ????????????201001?012011111102?100000?????? \\
\hline Neoaetosauroides & $121111111 ? ? 02000000 ? 000002 ? 0010 ? 000000100001$ \\
\hline Typothorax & $121111 ? 1011121011001001221001100010010 ? ? ? ? ? 0$ \\
\hline Redondasuchus & ????????????21?11001??1?????????0000???????? \\
\hline Tecovasuchus & ????????????21000101?10221??121?001020?????? \\
\hline Acaenasuchus & ????????????20?101?012011???202?00000??????? \\
\hline Sierritasuchus & ????????0112011001012111??202?00000???????? \\
\hline Aetobarbakinoides & ?????????0011??00??0??1?????????00?????????? \\
\hline Polesinesuchus & ?????????0?110?00000??1???0?10?00??????????? \\
\hline Paratypothorax type & ?????????11?11000100111221??221?1??020?????? \\
\hline P. SMNS 19003 & $01101101 ? ? ? ? 1100010 ? 1112210 ? 221 ? 1 ? 0020111111$ \\
\hline Stenomyti & 011111010???20000?000000020?010?0?0000101102 \\
\hline
\end{tabular}


